\title{
Do board characteristics mitigate real and accrual- based earnings management activities? Evidence from MENA countries
}

\author{
Taha Suleiman Almarayeh \\ Assistant professor at the Department of Accounting of American University of Madaba (Jordan)
}

\begin{abstract}
Using a sample of 915 MENA firms -year observations for the period of 2007 to 2017, we study the impact of board of directors' characteristics on accrual and real - based earnings management as measured by discretionary accruals and abnormal discretionary expense. To this end, we develop two empirical models based on ten testable research hypotheses. We find that both predictor variables - board meeting and CEO duality (partial) - are negatively associated with earnings management. While, other predictor variables, such as board size, board independence, and gender diversity, have no crucial role in alleviating earnings management. Our findings tend to confirm that an effective board director system in the Anglo Saxon may not be as effective in developing economies because of its unique characteristics of the board directors, CG system, and legal environment.
\end{abstract}

Key words: Earnings management, board of directors, MENA countries.

\section{Introduction}

Following the corporate scandals in the 1990s/2000s and the 2007/08 global financial crisis, many developing countries have given more attention to the corporate governance (henceforth CG) reforms. Since weak governance has been considered as one of the key reasons that threating the shareholder wealth(Baek et al. 2004; Lemmon and Lins 2003).

Many Middle Eastern and North African (henceforth MENA) nations among other group of emerging markets walked down the way to reform their CG by embracing several governance mechanisms from developed countries. The corporate board is an example of these fundamental governance mechanisms.

This study, therefore, searches the degree of the effectiveness of CG in mitigating earnings management, in the setting of emerging economies. In particular, our focus is on board of directors and its effect on accrual and real - based earnings management as measured by discretionary accruals and abnormal discretionary expense, respectively, in MENA nations which provide a rich empirical environment to link corporate board and earnings management. 


\title{
$7^{\text {th }}$ International Conference On Opportunities and Challenges In MANAGEMENT, ECONOMICS and ACCOUNTING
}

\author{
18-20 June, 2021 \\ Brussels, Belgium
}

Over the past two decades, earnings management has gained more and more scholarly attention. In this side, Kim and Yi (2006) report that a significant drop in firms' earnings during a post-crisis period leds firms to manipulate their income more aggressively.

Earnings management is defined as "the practice of distorting the true financial performance of the company" (Klein 2002, p.376). Another definition is also proposed by Scott (1997, p.369) as follow "earnings management is the choice by a manager of accounting policies so as to achieve a specific objective."

Indeed, EM happens when directors intervene in the financial reporting process by utilizing discretion and judgment regarding accounting options, with the intent to either mislead stakeholders about the underlying financial performance of the company or to influence contractual outcomes that depend on announced accounting figures (Healy and Wahlen 1999; Kothari et al. 2015). Scholars such as (Badertscher 2011; Healy and Wahlen 1999; Roychowdhury 2006; Schipper 1989) indicate that directors can use two main earnings management strategies to manage their earnings, namely accrual-based (manipulation of profits through using accounting discretion) and real activity earnings management (Abnormally high production of inventory, Sales price reductions and flexible credit terms, Delay investment projects and production costs).

Fan and Wong (2002) noticed that the ownership concentration in Asian family firms has an entrenchment influence to diminish financial reporting quality. Further, Li et al. (2011) and Li et al. (2014) found that companies in developing economies tend to manage their earnings more than counterparts in developed economies.

Despite a considerable amount of literature on the earnings management in the developed market economies (Davidson et al. 2005; Niu 2006; Osma 2008; Park and Shin 2004; Xie et al. 2003), countries in the MENA have received very little attention, and CG investigation in this area remains undeveloped.

Needless to say, developing economics depict vast contrasts in comparison with developed nations regarding low market, more volatility, smaller size, and information efficiency (Kumar and Tsetsekos 1999). Consequently, an effective board directors system in the Anglo Saxon may not be as effective in developing economies because of its unique characteristics of the board directors, CG system and legal environment. Moreover, the efficiency of a bunch of governance mechanisms differs systematically with the institutional structure at the country levels. (La Porta et al. 2002; Lubatkin et al. 2007; Suhomlinova 2006). In this respect, Millar et al. (2005) describe the divergence in institutional setting by suggesting an "international triad" of business systems (Anglo-Saxon, communitarian and emerging), which in turn, reflecting the variations among nations from multiple aspects (i.e., institutional context, economic, cultural factors and investor protection regimes). 


\title{
$7^{\text {th }}$ International Conference On Opportunities and Challenges In MANAGEMENT, ECONOMICS and ACCOUNTING
}

\author{
18-20 June, $2021 \quad$ Brussels, Belgium
}

Despite much of the empirical research on CG based on the agency theory (Daily et al. $2003)^{1}$ far too limited attention has been granted to how earnings management behavior varies in nations that have drastically different national institutional environments and firmownership structures (Bao and Lewellyn 2017). Thus, agency theory may not sufficiently interpret the variation in earnings management phenomenon. On the other hand, the mixture of agency and institutional theories allow to understand institutional framework in which organizations are operate. Seal (2006) indicate that Institutionalized agency theory combines the routine kind of managerial accounting practices with outside institutional impacts. As a result, the institutionalized agency theory appears as a proper framework to conceptualize the control/monitoring role of the board of directors on earnings management in a such an institutional environments.

In reality, our choice to focus on MENA developing markets is driven by several reasons. First, this kind of empirical evidence can afford relevant and valuable insights into the current debate regarding the capability of CG mechanisms in monitoring managerial behavior, especially in emerging markets, including MENA countries. Second, in the term of legislation environment, MENA emerging economies have experienced significant changes in the last decades. In particular, most of MENA nations have furthered CG improvements by promulgating national CG codes, UK-style voluntary "comply or explain" (Al-Bassam et al. 2018; Elghuweel et al. 2017; Pillai and Al-Malkawi 2018). Third, the institutional setting of the MENA emerging economies, which is generally characterized by lower investor protection, a code law tradition. Further, many scholars (i.e.,Al-Bassam et al. 2018; Md Zaini et al. 2018) show that the MENA context has unique cultural characteristics i.e, strong hierarchical social structures. Thus, with this scenario, more attention is given to casual relations, such as family loyalty, norms, and tribalism than formal CG and accountability mechanics such as corporate boards, when making critical corporate decisions (Al-Bassam et al. 2018; Habbash and Alghamdi 2017; Md Zaini et al. 2018). Moreover, in the MENA economies, the family business represents a usual style for business organization and, In contrast to developed countries, businesses' structure ownership is concentrated and intimately bound to a small group of people. Arguably, these environmental settings bring up serious empirical question as to whether CG mechanisms may differ under an environmental business structure. Consequently, the purpose of our study is to test the effect of the board of director's characteristics on earnings management behavior in MENA countries.

The examination of corporate board and earnings management in emerging nations, where there is a lack of empirical evidence, is crucial in offering a further comprehensive understanding regarding CG reformations and their appropriateness to those countries, and thereby, this research contributes to the literature in several ways. First, we extend the literature that examines the role of the board of director's characteristics in decreasing earnings management behavior in MENA region, which is presented a useful empirical setting due to the distinctiveness of its institutional context from the frequently studied Anglo-Saxon context. The best of our knowledge, no study has yet examined the potential association between the

\footnotetext{
${ }^{1}$ According to Daily et al (2003) agency theory dominates governance research due to two factors:: "First, it is an extremely simple theory, in which large corporations are reduced to two participants - managers and shareholders - and the interests of each are assumed to be both clear and consistent. Second, the notion of humans as self-interested and generally unwilling to sacrifice personal interests for the interests of others is both age old and widespread".
} 


\section{$7^{\text {th }}$ International Conference On Opportunities \\ and Challenges In MANAGEMENT, ECONOMICS and ACCOUNTING}

\section{8-20 June, $2021 \quad$ Brussels, Belgium}

board of director's characteristics and both types of earnings management behavior within the MENA setting. Second, our study affords multi-country evidence on the influence of the board of director's characteristics and earnings management behavior. Thus, our research is different from prior MENA studies that tested corporate board in that they are exclusively individual country-focused. Besides, it distinguishes itself from other related studies by employing observations over eleven years. Therefore, it provides a better inference. Third, theoretically, we open the door and contribute to emerging attempts to integrate "institutionalized agency theory perspective" within CG investigation.

The results are based on a sample of 915 firm-year observations from MENA countries over the duration 2007-2017. The study presents empirical evidence revealing that both predictor variables - board meeting and CEO duality (partial) - are negatively associated with earnings management. Moreover, the evidence presented that other predictor variables, such as board size, board independence, and gender diversity, have no crucial role in alleviating earnings management.

The article then continues as follows. The next section presents an overview of the MENA countries, while Section 3 devotes to the theoretical background, prior literature, and hypotheses formulation. Section 4 contains the research design and methodology. The empirical analysis is elucidated in Section 5, followed by our robustness checks in Section 6. We present our discussion in Section 7. And the article concludes with implications, limitations, and future research directions in Section 8.

\section{The governance environment in MENA emerging markets: an overview}

As in much of developing countries, most of MENA countries governments have adopted the rules of corporate governance, as a reaction for calls of Globalization, worldwide trade, and universal investment practices. Table 1 provides a main characteristics of CG codes in the MENA.

\section{Insert Table 1 here}

The institutional setting in developing countries, as in case of MENA countries, leds the CG mechanisms to operate differently than those in developed countries (Almarayeh 2019). In particular, whereas some countries have been introduced principal changes in their laws and regulations (e.g., Anglo-Saxon countries), others were more partial compliance and changed only some specific aspects (e.g., Turkey and Arab countries). Relatedly, in many cases, new reforms of the CG code give the flexibility to which firms voluntary can adhere (Comply or explain approach). In addition, the governance landscape in the MENA countries vary among them. Where every country set up his standards in view of its history and culture.

The MENA countries espouse a civil law legal system which is intensely affected by deep cultural and political bonds. Besides, they sharing many cultural, social, political identities, economic features, and follow a common rooted Islamic beliefs (Sarhan and Ntim 2019a). As per Al-Ajmi (2009) noticed that MENA countries give more attention to informal 


\title{
$7^{\text {th }}$ International Conference On Opportunities and Challenges In MANAGEMENT, ECONOMICS and ACCOUNTING
}

\author{
18-20 June, 2021 \\ Brussels, Belgium
}

relations that are usually based on family values. Further, personal relationships have a strong influence in business processes.

With the ongoing debate on institutional context, corporate environment in the MENA area along with it's the stock markets has some distinct attributes that are not quite the same as those of most developed nations. For example and generally, most firms are still controlled by family ownership, especially royal families (Ben-Hassoun et al. 2018; Habbash and Alghamdi 2017). Moreover, Ben-Hassoun et al. (2018) argue that companies in this area continue to face a relatively weak legal enforcement, weak institutional environments, heavy bureaucracy or corrupt political institutions. Consequently, the level of protection to investors and minority shareholders is tend be lower than those of developed economies (Berkowitz et al. 2003; Iatridis 2012; Omran et al. 2008).

\section{Theoretical background and hypotheses}

\subsection{Board size and earnings management}

Many Scholars have confirmed that the board size play a crucial role in monitoring the firm's activities (Peasnell et al. 2005; Xie et al. 2003). Relatedly, prior literature have discussed the optimal size of the board to fulfill its role in surveillance effectively (Jensen 1993; Lipton and Lorsch 1992; Rahman and Ali 2006; Yermack 1996).

Several arguments, interpret the vantages of smaller boards. For example, less complicated, which is help to carry out its tasks completely (Lipton and Lorsch 1992; Jensen 1993; Vafeas 2000). More efficient in monitoring the quality of financial reporting and the information content of earnings would be higher (Vafeas 2000). Furthermore, manipulation on board members' evaluation of top executives becomes more easily when boards are large (Mintzberg and Mintzberg 1983). While, other arguments indicate that larger board may be able to face any irrational decisions made by the CEO (Forbes and Milliken 1999). Besides, it is less likely to be controlled by management (Xie et al. 2003).

Mixed findings have surfaced in prior literature, as Xie et al. (2003), Chtourou et al. (2001), and Bradbury et al. (2006) found a negative relationship between board size and discretionary accruals as a proxy for earnings management, Rahman and Ali (2006) and Ching et al. (2006) report a positive association. Other scholars, such as Jaggi et al. (2009), did not entirely succeed in uncovering a significant relationship. Similarly, Indecisive outcomes have also appeared in prior investigation among board size and real earnings management. For example, Chouaibi et al. (2016),Hsu and Wen (2015), Kang and Kim (2012) and Rossi and Cebula (2015) observed a negative influence of board size on the real earnings management. However, another group of scholars, such as Garven (2015) and Visvanathan (2008) has been unable to find any correlation between board size and the real-based earnings management activities. 


\title{
$7^{\text {th }}$ International Conference On Opportunities and Challenges In MANAGEMENT, ECONOMICS and ACCOUNTING
}

\author{
18-20 June, 2021 \\ Brussels, Belgium
}

In the developing countries (see Table 1), the enactment code of CG introduced significant changes by mandating specific practices, such as an adequate number of the member board size. Which in turn, providing valuable advice and accelerating in making right decisions. In addition, the negative association revealed in early investigation collected in emerging markets( i.e., Singapore and Tunisia ) by Bradbury et al. (2006) and Chouaibi et al. (2016) heads to the current research hypothesizing a negative relationship between board size and earnings management types.

H1a: All other things being equal, there is a negative relation between board size and discretionary accruals.

H1b: All other things being equal, there is a negative relation between board size and the abnormal discretionary expense.

\subsection{The proportion of independent board members and earnings management}

Existing non-executive directors is assumed to monitor top management, reduce agency costs as per the agency theory. Besides, lead to more reliable financial statements (Beasley 1996; Brennan and McDermott 2004). For example, Beasley (1996) indicated that firms with a larger proportion of outside members are less inclined to fall into the mistakes of fraudulent financial reporting.

Much of the prior Studies based on Anglo-Saxon data (i.g., the UK, the US and Canada) have generally found that an independent board helps to decrease the chances of earnings management (Beasley 1996; Niu 2006; Osma 2008; Peasnell et al. 2000a; Peasnell et al. 2005). While other evidence that comes from many developing countries has been shown insignificant relation between non-executive directors and both accrual-based and real activity earnings management (see i.e., Bradbury et al. 2006; Hsu and Wen 2015; Ianniello 2015; Jaggi et al. 2009; Rossi and Cebula 2015). Studies by Chouaibi et al. (2016) and Kang and Kim (2012) advocate the existing non-executive directors minimizing earnings management in the developing countries setting.

Such inconsistent and contradictory evidence affirms the call of further research. Further, given to the institutional setting in emerging market which is characterized by a unique features such as, such as highly concentrated ownership, culture dimensions as personal loyalties are employed in business activities further serves as a reason to hypothesize a nonrelation between board independence and earnings management.

H2a: All other things being equal, non-executive directors have not affected negatively on the level of discretionary accruals.

$\mathrm{H} 2 \mathrm{~b}$ : All other things being equal, non-executive directors have not affected negatively on the level of abnormal discretionary expense. 


\title{
$7^{\text {th }}$ International Conference On Opportunities and Challenges In MANAGEMENT, ECONOMICS and ACCOUNTING
}

\author{
18-20 June, 2021 \\ Brussels, Belgium
}

\subsection{CEO Duality and earnings management}

The term of 'CEO Duality' is generally understood to refer to a situations in which the chairman and the CEO positions are occupied by the same person. Theories in this area offer seemingly opposite views on the dual leadership structure of CEO and chairman positions on the board. Agency theory tenets indicate that the position of the chief executive and board chair should be separated in order to distinguish corporate control from management decisions (Iqbal et al. 2019). Besides, information asymmetry problems are more likely to increase since the CEO can hide information from the other board member, and therefore, limiting their monitoring role (Alves 2012). Stewardship theory argues that the dual position of CEO and chairman enables management to take autonomous executive actions (Davis et al. 1997). Chang and Sun (2009) contend that a single head can provide a precise direction . In addition, CEO duality enables to consolidate the management of company, which in turn, would be helped on the continuity and stability. This stability enhances, therefore, the functioning of the board (Brickley et al. 1997).

Empirically, the relationship between CEO duality and earnings management is inconclusive. Some Anglo Saxon researchers (Davidson et al. 2005; Ghosh et al. 2010; Xie et al. 2003) found that CEO duality was unrelated to earnings management. Others scholar such as, Dechow et al. (1996) reported a positive relationship among two. The same mixed findings are documented in developing markets (see for i.e., Alzoubi 2016; Bao and Lewellyn 2017; Bradbury et al. 2006; Chi et al. 2015). Based on the above theoretical and empirical literature, we assume CEO duality to have a significant impact on earnings management, but the hypothesized correlation can be either negative or positive.

H4a: All other things being equal, there is a significant relationship between CEO duality and discretionary accruals.

H4b: All other things being equal, there is a significant relationship between CEO duality and the abnormal discretionary expense.

\subsection{Board activity and earnings management}

Board meeting serve as a signal of board effectiveness, and it represents an important dimension of the board's work (Conger et al. 1998; Jensen 1993; Vafeas 1999). Prior regulation and laws (i.e., Cadbury Report 1992; BRC 1999; SEC 1999; SOX 2002) emphasize the value of annual board meeting. Conger et al. (1998) and Jensen (1993) add that the board needs to organize the frequency of meetings as a group to fulfill its role effectively. As Menon and Williams (1994) note that boards may not be effective monitors, if they held their meeting a few times during the year. In this side, US studies document a negative relationship between board activity and earnings management (Vafeas 1999; Xie et al. 2003). Relatedly, other group of scholars (i.e., Jensen 1993; Lorca et al. 2011) present a contrary opinion, and they argue that the limited time available to the directors and CEO's, would be consumed in routine duties 


\title{
$7^{\text {th }}$ International Conference On Opportunities and Challenges In MANAGEMENT, ECONOMICS and ACCOUNTING
}

\author{
18-20 June, 2021 \\ Brussels, Belgium
}

and not for controlling the management team. However, research in this domain were not able to agree on an accurate average number of meetings.

In hypothesizing a specific association, firstly all CG codes in emerging markets support board activity by enactment a particular number of meeting held by board members yearly. Secondly, consistent with previous literature emerged from the emerging markets setting (see for i.e., Chouaibi et al. 2016; González and García-Meca 2014) negative correlation is hypothesized between board meeting and earnings management.

H3a: All other things being equal, there is a negative relation between board meeting and discretionary accruals.

$\mathrm{H} 3 \mathrm{~b}$ : All other things being equal, there is a negative relation between board meeting and the abnormal discretionary expense.

\subsection{Gender Diversity and earnings management.}

Gender diversity refers to a situation where the female directors are occupied a percentage in the board. Zalata et al. (2018) mentioned that the existence of female directors in the board is probably to enhance the shareholders' wealth and improve board independence. Studies in this regard present several advantages of the female directorship, one is professional backgrounds different from those of the "old boys' club." which they are more probably help to provide greater oversight, monitoring (Adams and Ferreira 2009). Another is active attendance, and they are demanding to greater accountability from CEOs for bad performance (Gul et al. 2011). Moreover, female managers are more compliant with moral standards in their decision (Krishnan and Parsons 2008).

However, various arguments exhibit another side for the female directorship. Torchia et al. (2011) indicate that diversity may lead to tokenism if female board individuals are not adequately numerous. Further, it may also cause lower cohesiveness due to shortage of interactions amongst board individuals (Herring 2009).

Given to these opposing arguments, previously published studies on the potential effect of gender diversity on earnings management are inconsistent and ambiguous results. The relationship is founded to be negative (Arun et al. 2015; Triki Damak 2018; Gavious et al. 2012), positive (Debnath et al. 2019; Rossi and Cebula 2015) and sometimes statistically non significant (Abdullah and Ismail 2016; Peni and Vähämaa 2010; Sun et al. 2011). Based on the previous debate we presume gender diversity to have a significant influence on earnings management, but the hypothesized association can be either negative or positive.

H5a: All other things being equal, there is a significant relationship between gender diversity and discretionary accruals.

H5b: All other things being equal, there is a significant relationship between gender diversity and the abnormal discretionary expense. 


\title{
$7^{\text {th }}$ International Conference On Opportunities and Challenges In MANAGEMENT, ECONOMICS and ACCOUNTING
}

\author{
18-20 June, 2021 \\ Brussels, Belgium
}

\section{Research design and methodology}

\subsection{The sample}

To analyse the potential role of board of director' characteristics on the earnings management, we employ a sample of 915 firm-year observations for 168 firms. To construct this sample, we select all non-financial firms that listed in the stock exchanges of the MENA countries for an eleven-year period ranging from 2007 to 2017. There are 1855 observations; however 936 observations have been eliminated due to four reasons such as (i) missing board of director's data (ii) lack of data for control variables calculations (iii) lack of data for earnings management proxy calculations (iv) non availability of data for the research period 2007-2017. As a result the final sample consists of 915 firm-year observations distributed among 10 countries namely: United Arab Emirates, Bahrain, Egypt, Qatar, Saudi Arabia, Kuwait, Oman, Morocco, Turkey and Jordan (52, 34, 64, 67, 82, 71, 68, 24, 202 and 251, respectively). Table 2 shows the distribution of observations by country. To examine the data, pooled cross-sectional data analysis will be carried to reflect different distributions during different time periods (Wooldridge 2003). Panel data helps to raise the sample size and, thus, increases the number of degrees of freedom, enhancing the efficiency of estimates(Hsiao et al. 1995). Besides, it helps to decrease the problems of multicollinearity (Hsiao 2007; Gebhardt and NovotnyFarkas 2011).

\begin{tabular}{ll} 
Table 2 number of observations by country \\
\hline Country & Observation \\
\hline United Arab Emirates & 52 \\
Bahrain & 34 \\
Egypt & 64 \\
Qatar & 67 \\
Saudi Arabia & 82 \\
Kuwait & 71 \\
Oman & 68 \\
Morocco & 24 \\
Turkey & 202 \\
Jordan & 251 \\
\hline Global & 915 \\
\hline
\end{tabular}




\title{
$7^{\text {th }}$ International Conference On Opportunities and Challenges In MANAGEMENT, ECONOMICS and ACCOUNTING
}

\author{
18-20 June, 2021 \\ Brussels, Belgium
}

\subsection{Measurement of variables}

\subsubsection{Earnings management}

Earnings management involves accrual-based and real activity earnings management. Consonant with the prior literature, we employ the absolute value of discretionary accruals |DA| as a proxy for accrual earnings management (Bergstresser and Philippon 2006; Jiang et al. 2010). Discretionary accruals are calculated cross-sectionally, as the residual from the following regression model (Kothari et al. 2005). Kothari et al.'s (2005) performance adjusted model has a higher power of determination of earnings management and fewer misspecification problems comparing with other models such as the Jones model (1991) and the modified Jones Model (Dechow et al. 1995).

TAi,t $/ A i, t-1=\alpha 0, \mathrm{t}+\alpha 1, \mathrm{t}(1 / \mathrm{Ai}, \mathrm{t}-1)+\alpha 2, \mathrm{t}(\Delta($ SALES - REC $) \mathrm{i}, \mathrm{t} / \mathrm{Ai}, \mathrm{t}-1)+\alpha 3, \mathrm{t}(\mathrm{PPEi}, \mathrm{t} / \mathrm{Ai}, \mathrm{t}-1)$ $+\alpha 4, \mathrm{t}(\mathrm{ROAi}, \mathrm{t} / \mathrm{Ai}, \mathrm{t}-1)+\varepsilon \mathrm{t}$

where

TAi,t are the total accruals for firm $t$ in period $t$; Ai,t-1 are the total assets for firm $t$ in period $\mathrm{t} ; \Delta$ (SALES - REC)i,t represents the change in sales less accounts receivable for firm $t$ in period $\mathrm{t}$; PPEi,t reflects the property, plant and equipment for firm $\mathrm{t}$ in period $\mathrm{t}$; and ROAi, $\mathrm{t}$ is the return on assets for firm $t$ in period $t$.

As indicated by the earlier researchers (i.e.,Cohen and Zarowin 2010; Roychowdhury 2006), real earnings management comprise of three main types, namely: abnormal operating cash flow, abnormal discretionary expense and abnormal production costs. In this study, due to data availability, we utilize only abnormal discretionary expense as the proxy for real earnings management. Following Roychowdhury (2006), we use the following cross-sectional regression for each year and industry to estimate abnormal discretionary expense. We use the absolute value of abnormal discretionary expense to mark the magnitude of the manipulation rather than its direction.

$$
\operatorname{DISEXP}_{\mathrm{i}, \mathrm{t}} / \mathrm{A}_{\mathrm{i}, \mathrm{t}-1}=\alpha 0+\alpha_{1}\left(1 / \mathrm{A}_{\mathrm{i}, \mathrm{t}-1}\right)+\alpha_{2}\left(\mathrm{SALES}_{\mathrm{i}, \mathrm{t}} / \mathrm{A}_{\mathrm{i}, \mathrm{t}-1}\right)+\varepsilon \mathrm{t}
$$

Where:

DISEXP $_{i, t}$ : the sum of advertising expense, R\&D expense and SG\&A expense for year $t$ scaled by total assets in year $t-1 ; S A L E S_{i, t}$ is revenues of firm $i$ for period $t ; A_{i, t-1}$ is total assets of firm $i$ at the end of period t. All the variables are scaled by $\mathrm{A}_{\mathrm{i}, \mathrm{t}-1}$.

\subsubsection{The independent variables}

To test our hypotheses, we use five explanatory variables representing the board of directors' characteristics. The size of the board of directors (BRDSIZE) is measured as the total 


\title{
$7^{\text {th }}$ International Conference On Opportunities and Challenges In MANAGEMENT, ECONOMICS and ACCOUNTING
}

\author{
18-20 June, 2021 \\ Brussels, Belgium
}

number of members on the board of directors (Alves 2012; González and García-Meca 2014). Similar to (Bao and Lewellyn 2017; Chi et al. 2016; González and García-Meca 2014), the proportion of independent directors on the board (BRDIND) is measured by the ratio of nonexecutive directors on board to board size. It is worth notice that; we perceive that the extraction of these variables is a restriction of our research, where all firms in all countries do not necessarily utilize the same standards to define variables as of the board meeting in our case.

In Jordan, board meeting (BRDMEET) measured as a total number of meetings held annually by the board of directors as a proxy for board activity (Abdul Rahman and Ali 2006; Alves 2012; Chen et al. 2006; González and García-Meca 2014; Vafeas 1999; Xie et al. 2003). But in other MENA countries, it computed as the percentage of member's attendance in board meetings (Ammann et al. 2011; Kamal Hassan 2012). As defined by prior studies (Chi et al. 2015; Davidson et al. 2005; Goh and Rasli 2014; González and García-Meca 2014; Xie et al. 2003), CEO duality (BRDDUAL) is defined as a dummy variable that receives the value of 1 if the CEO serves as the chairman of the board and 0 otherwise. Following Bennouri et al. (2018), Gender Diversity (GENDIV) is computed as the proportion of female directors on the board. See Table 3 for more information about all variables.

\subsubsection{Models specification and control variables}

To examine the role of the board of director's characteristics on the earnings management, we use the following comprehensive models. In addition to the five main independent variables of the board of directors, the model incorporates a number of control variables recognized as important determinants of earnings management in previous research. Table 3 shows regression models and definition of the variables.

Table 3 Regression modelS and definition of the variables.

\begin{tabular}{|c|c|c|c|}
\hline \multicolumn{4}{|c|}{ 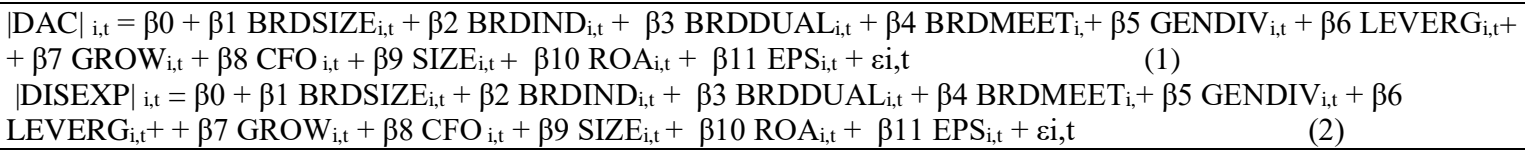 } \\
\hline Variable Name & Abbreviation & Definition & $\begin{array}{l}\text { Expected } \\
\text { sign }\end{array}$ \\
\hline \multirow{2}{*}{$\begin{array}{l}\text { Earnings } \\
\text { management } \\
\text { proxies }\end{array}$} & $|\mathrm{DAC}|_{\mathrm{i}, \mathrm{t}}$ & $\begin{array}{l}\text { Denotes the absolute value of discretionary accruals for firm } i \text { in } \\
\text { year t, from Kothary (2005) model }\end{array}$ & \\
\hline & $\mid$ DISEXP $\left.\right|_{i, t}$ & $\begin{array}{l}\text { Denotes the absolute value of abnormal levels of discretionary } \\
\text { expenses for firm i in year } t \text {, from Roychowdhury (2006) model }\end{array}$ & \\
\hline Board size & BRDSIZE $\mathrm{E}_{\mathrm{i}, \mathrm{t}}$ & Denotes the number of directors in the board for firm $\mathrm{i}$ in year $\mathrm{t}$ & - \\
\hline Board independence & BRDIND $_{\mathrm{i}, \mathrm{t}}$ & $\begin{array}{l}\text { Denotes the ratio of non-executive directors on board to board size } \\
\text { for firm } i \text { in year } t\end{array}$ & + \\
\hline CEO duality & BRDDUAL $L_{i, t}$ & $\begin{array}{l}\text { is a dummy variable denoting that the CEO is also Chairman for } \\
\text { firm i in year } t\end{array}$ & $+/-$ \\
\hline
\end{tabular}




\section{$7^{\text {th }}$ International Conference On Opportunities and Challenges In MANAGEMENT, ECONOMICS and ACCOUNTING}

\section{8-20 June, 2021}

$\begin{array}{lr}\text { Board meetings } & \text { BRDMEETi,t } \\ \text { Gender diversity } & \text { GENDIV }_{\mathrm{i}, \mathrm{t}} \\ \text { Firm leverage } & \text { LEVERG }_{\mathrm{i}, \mathrm{t}} \\ \text { Growth } & \text { GROW }_{\mathrm{i}, \mathrm{t}} \\ \text { Cash flow } & \text { CFO }_{\mathrm{i}, \mathrm{t}} \\ \text { Firm size } & \text { SIZE }_{\mathrm{i}, \mathrm{t}} \\ \text { Firm performance } & \text { ROA }_{\mathrm{i}, \mathrm{t}} \mathrm{t} \\ & \text { EPS }_{\mathrm{i}, \mathrm{t}} \\ & \\ \varepsilon_{\mathrm{i}, \mathrm{t}} & \varepsilon_{\mathrm{i}, \mathrm{t}}\end{array}$

\section{Brussels, Belgium}

- Denotes the number of board meetings over the calendar year for firm $i$ in year $t$

- Attendance of all members at least $75 \%$ in board meetings.

Denotes the proportion of female directors on the board for firm $\mathrm{i} \quad+/$ in year $\mathrm{t}$

Denotes the ratio of total debt to total assets for firm $\mathrm{i}$ in year $\mathrm{t}$

Denotes the relation of the difference in sales and sales of the previous period for firm $i$ in year $t$

Denotes the cash flow from operations for firm $\mathrm{i}$ in year $\mathrm{t}$

denotes the natural $\log$ of total assets for firm $\mathrm{i}$ in year $\mathrm{t}$

Denotes the return on assets for firm $\mathrm{i}$ in year $\mathrm{t}$

Denotes the ratio of income before extraordinary items divided by total number of shares outstanding for firm $i$ at the end of the fiscal year $\mathrm{t}$

is the error term

The first control variable is Leverage (LEVERG), computed as the ratio of total debts to total assets. As revealed by (Jaggi and Lee 2002; Jeong and Rho 2004; Jha 2013; Franz et al. 2014) firms with high financially distressed tend to manage earnings upwards(downwards) in order to avoid the technical default of their debt covenants ( in order to take advantage of restructuring debt as well as renegotiating of debt agreements. The predicted association with $\mathrm{EM}$ is positive.

The next control variable is growth (GROW) which captured the manager's intention regarding accomplishing a targeted growth degree, or to hide downturns, and it is calculated by the difference in sales and sales of the previous period. As noted by Skinner and Sloan (2002) and Carcello and Nagy (2004) managers who aim to achieve certain return thresholds have more incentives to manipulate their income, thus a positive coefficient with EM is expected.

Furthermore, we employ the Cash flow variable (CFO), which is a gauge of the quantity of cash generated by a firm's normal business processes scaled by total assets. As indicated Roychowdhury (2006), firms with a higher CFO are less likely to manage their income.. Thus, we foretold a positive sign between CFO and EM.

The next control variable is size (SIZE), measured as the natural log of total assets. As indicated by prior scholars (i.e.,Krishnan 2003; Piot and Janin 2007) big firms engage less in earnings management. In particular,Park and Shin (2004) and Sánchez- Ballesta and GarcíaMeca (2007) contend that larger firms are subject to more attention by the external capital market, with a closely controlled by the journalists and analysts, and consequently they are less ready to conceal earnings malpractices; a negative relationship with EM is therefore expected.

Finally, we include two control variables on firm performance. The first is the variable return on asset (ROA), measured by dividing a firm's net income by its total assets. The second is the variable earnings per share (EPS), calculated as income before extraordinary items divided by 


\title{
$7^{\text {th }}$ International Conference On Opportunities and Challenges In MANAGEMENT, ECONOMICS and ACCOUNTING
}

\author{
18-20 June, 2021 \\ Brussels, Belgium
}

total number of shares outstanding at the end of the fiscal year. Prior scholars (i.e.,Ashari et al. 1994; Rahman and Ali 2006; Lin et al. 2009) argued that firms with lower profit and managers who perform poorly, are more inclined to join in earnings management, and accordingly, a positive sign with EM is foreseen for both.

\subsection{Descriptive statistics}

Table 4 reports descriptive statistics for the two main dependent variables, including discretionary accruals and the abnormal levels of discretionary expense as a proxy for accrualbased and real activity earnings management, respectively.

Regarding discretionary accruals, Table 4 shows that Jordanian firms have the highest mean of discretionary accruals, with $0.097 \%$, followed by Qatar $0.062 \%$, Moroccan $0.056 \%$, and Egyptian $0.048 \%$ firms. While, Omani and Saudi firms recorded the lowest mean of discretionary accruals by 0.021 and 0.025 , respectively. The mean value of discretionary accruals for the overall sample is $0.053 \%$.Furthermore, With reference to the abnormal discretionary expense, as is evident from Table 4, Moroccan firms scored the highest mean of the abnormal discretionary expenses, with $0.153 \%$, followed by Bahraini firms $0.124 \%$, and then, by Jordanian and UAE firms, which exhibited the same score of $0.108 \%$. In contrast, countries such as Kuwait and Qatar scored the lowest average by $0.022 \%$ and $0.045 \%$, respectively. The mean value of the abnormal discretionary expenses, for the overall sample is 0.083 which indicate that managers are more likely prefer managing earnings by real activities rather than accruals (see i.e.,Cohen and Zarowin 2010; Roychowdhury 2006).

Table 5 presents the main descriptive statistics (Mean and Std. Dev.) of quantitative and dichotomous variables. Table 5 reveals that the average board size in the full sample is 9.348 (9). We also observed that on average, $36.675 \%$ of the members are independent in the whole sample, but in general, this figure has slightly varied between ten countries analyzed. Table 5 also displays that the chairperson of the board is also the CEO for $58.03 \%$ of the observed firm-years. It also shows that the mean frequency of board meeting is 7.3 times in a year for Jordan and it ranges among 80.706 to $92.231 \%$ for other countries. For gender diversity variables, the average percentage of female board members is $7.526(8) \%$ in the whole sample.

Table 6 presents the pearson's correlation matrix between variables. It shows that there are numerous statistically significant correlations among variables. However, all correlation coefficients are less than the crucial threshold of 0.8 . VIF values go somewhere in the range of 1.039 and 2.48 , considerably below the critical value of 10 , which means that our analysis is free from the multicollinearity problems. 


\title{
$7^{\text {th }}$ International Conference On Opportunities and Challenges In MANAGEMENT, ECONOMICS and ACCOUNTING
}

\author{
18-20 June, $2021 \quad$ Brussels, Belgium
}

Table 4 Descriptive statistics of discretionary accruals and abnormal discretionary expenses, estimations by country.

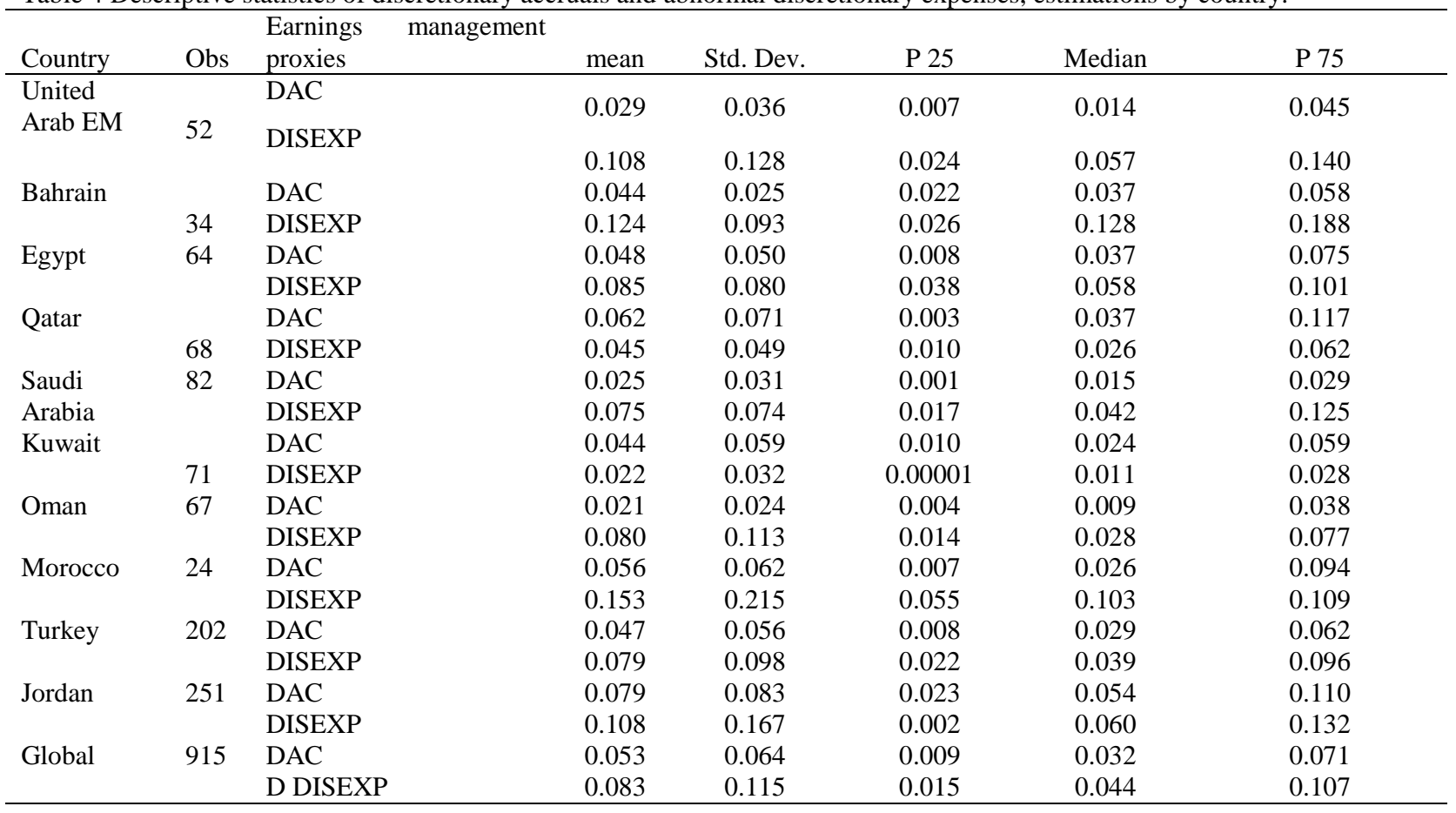




\section{$7^{\text {th }}$ International Conference On Opportunities and Challenges In MANAGEMENT, ECONOMICS and ACCOUNTING}

\section{8-20 June, $2021 \quad$ Brussels, Belgium}

Table 5 Descriptive Statistics $\uparrow$.

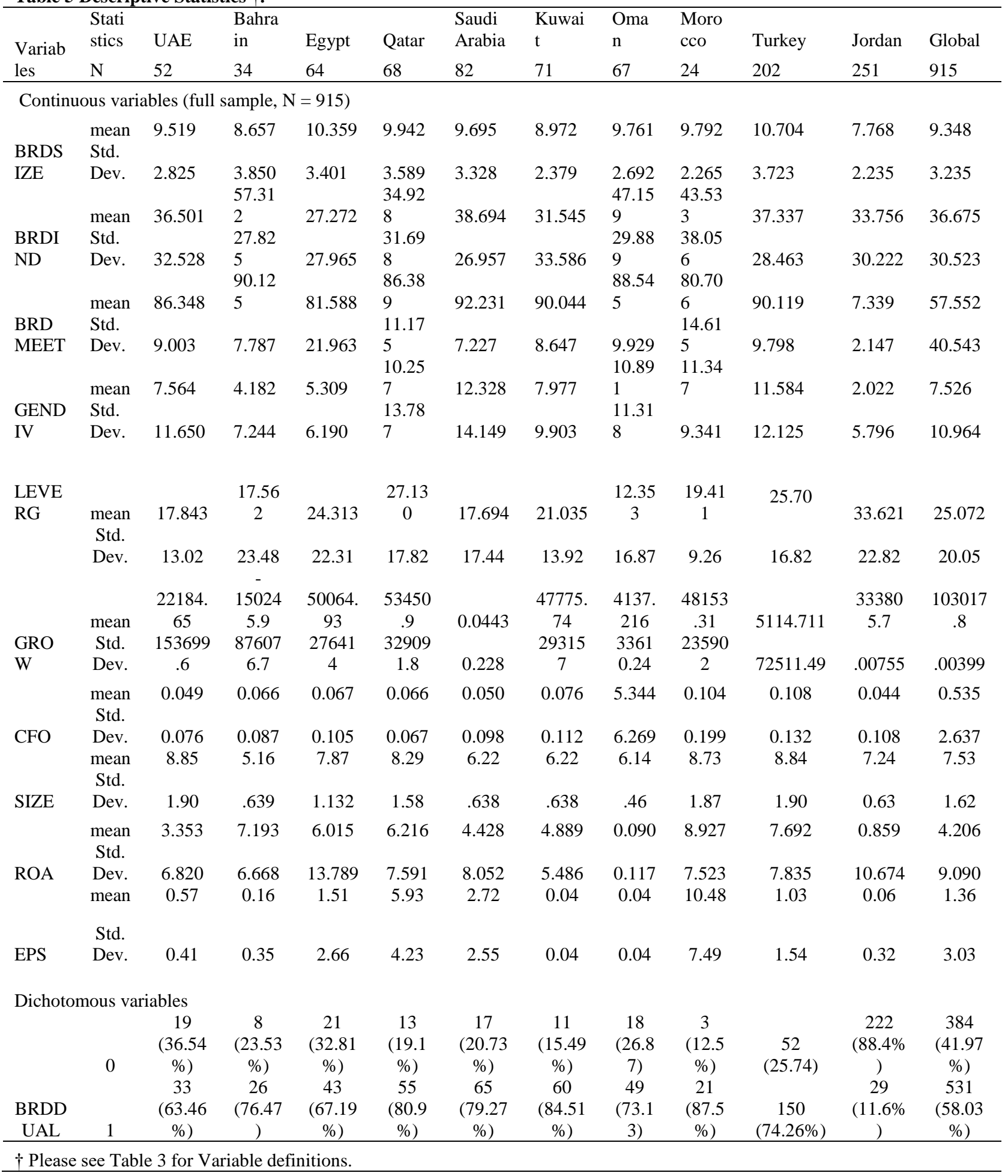




\section{$7^{\text {th }}$ International Conference On Opportunities}

and Challenges In MANAGEMENT, ECONOMICS and ACCOUNTING

\section{8-20 June, 2021 Brussels, Belgium}

Table 6 the Pearson's correlation matrix and VIF values.

\begin{tabular}{|c|c|c|c|c|c|c|c|c|c|c|c|c|c|c|}
\hline $\begin{array}{l}\text { Variabl } \\
\text { es } \dagger\end{array}$ & DAC & $\begin{array}{l}\text { DISE } \\
\text { XP }\end{array}$ & $\begin{array}{l}\text { BRDS } \\
\text { IZE }\end{array}$ & $\begin{array}{l}\text { BRDI } \\
\text { ND }\end{array}$ & $\begin{array}{l}\text { BRD } \\
\text { DUA }\end{array}$ & $\begin{array}{l}\text { BRD } \\
\text { MEET }\end{array}$ & $\begin{array}{l}\text { GEN } \\
\text { DIV }\end{array}$ & $\begin{array}{l}\text { LEV } \\
\text { ERG }\end{array}$ & $\begin{array}{l}\text { GRO } \\
\text { W }\end{array}$ & $\mathrm{CFO}$ & SIZE & $\begin{array}{l}\text { RO } \\
\mathrm{A}\end{array}$ & $\begin{array}{l}E \\
P \\
S\end{array}$ & VIF \\
\hline DAC & 1 & & & & & & & & & & & & & \\
\hline $\begin{array}{l}\text { DISEX } \\
\mathrm{P}\end{array}$ & -0.0086 & 1 & & & & & & & & & & & & \\
\hline $\begin{array}{l}\text { BRDSI } \\
\text { ZE }\end{array}$ & -0.0196 & $\overline{-} .093$ & 1 & & & & & & & & & & & 1.3 \\
\hline $\begin{array}{l}\text { BRDIN } \\
\text { D }\end{array}$ & -0.065 & 0.076 & -0.051 & 1 & & & & & & & & & & 1.2 \\
\hline $\begin{array}{l}\text { BRDD } \\
\text { UA }\end{array}$ & -0.058 & $\begin{array}{l}- \\
0.168 \\
* *\end{array}$ & $\begin{array}{l}0.160 \\
* *\end{array}$ & -0.065 & 1 & & & & & & & & & $\begin{array}{l}2.4 \\
8\end{array}$ \\
\hline $\begin{array}{l}\text { BRDM } \\
\text { EET }\end{array}$ & $\begin{array}{l}- \\
0.181 * \\
*\end{array}$ & $\begin{array}{l}- \\
0.137 \\
*\end{array}$ & $\begin{array}{l}0.322 \\
* * *\end{array}$ & $\begin{array}{l}0.212 \\
* * *\end{array}$ & $\begin{array}{l}0.600 \\
* * *\end{array}$ & 1 & & & & & & & & 1.9 \\
\hline $\begin{array}{l}\text { GENDI } \\
\mathrm{V}\end{array}$ & -0.093 & $-\overline{0}$ & $\begin{array}{l}0.230 \\
* * *\end{array}$ & $\begin{array}{l}0.240 \\
* * *\end{array}$ & $\begin{array}{l}0.210 \\
* * *\end{array}$ & $\begin{array}{l}0.480 * \\
* *\end{array}$ & 1 & & & & & & & $\begin{array}{l}1.3 \\
8\end{array}$ \\
\hline $\begin{array}{l}\text { LEVER } \\
\mathrm{G}\end{array}$ & 0.06 & $\begin{array}{l}0.144 \\
*\end{array}$ & 0.015 & $\begin{array}{l}- \\
0.158 \\
* *\end{array}$ & -0.013 & $\begin{array}{l}- \\
0.215^{*} \\
* *\end{array}$ & $\begin{array}{l}- \\
0.105\end{array}$ & 1 & & & & & & $\begin{array}{l}1.1 \\
8\end{array}$ \\
\hline GROW & $0.121 *$ & 0.015 & 0.013 & 0.052 & -0.059 & 0.019 & - & $\begin{array}{l}- \\
0.03 \\
9\end{array}$ & 1 & & & & & $\begin{array}{l}1.0 \\
3\end{array}$ \\
\hline $\mathrm{CFO}$ & $\begin{array}{l}0.305 * \\
* *\end{array}$ & $-\overline{0}$ & $\begin{array}{l}0.184 \\
* *\end{array}$ & -0.047 & $\begin{array}{l}0.133 \\
*\end{array}$ & $0.125^{*}$ & 0.049 & $\begin{array}{l}0.05 \\
9\end{array}$ & 0.102 & 1 & & & & $\begin{array}{l}1.1 \\
4\end{array}$ \\
\hline SIZE & $\begin{array}{l}- \\
0.258 * \\
* *\end{array}$ & 0.052 & 0.025 & 0.037 & -0.019 & $0.133^{*}$ & 0.035 & $\begin{array}{l}0.08 \\
2\end{array}$ & - & $-\overline{0.0047}$ & 1 & & & $\begin{array}{l}1.0 \\
8\end{array}$ \\
\hline ROA & -0.019 & 0.091 & $\begin{array}{l}0.179 \\
* *\end{array}$ & 0.029 & 0.045 & 0.107 & 0.105 & $\begin{array}{l}- \\
0.04 \\
9\end{array}$ & $\begin{array}{l}- \\
0.036\end{array}$ & -0.106 & -0.077 & 1 & & $\begin{array}{l}1.2 \\
4\end{array}$ \\
\hline EPS & -0.067 & $\begin{array}{l}0.030 \\
4\end{array}$ & $\begin{array}{l}0.256 \\
* * *\end{array}$ & $\begin{array}{l}0.148 \\
*\end{array}$ & $\begin{array}{l}0.242 \\
* * *\end{array}$ & $\begin{array}{l}0.321 * \\
* *\end{array}$ & $\begin{array}{l}0.146 \\
*\end{array}$ & $\begin{array}{l}0.04 \\
3\end{array}$ & $\begin{array}{l}- \\
0.009\end{array}$ & $\begin{array}{l}0.363 * \\
* *\end{array}$ & $\begin{array}{l}0.275 * \\
* *\end{array}$ & $\begin{array}{l}0.02 \\
6\end{array}$ & 1 & $\begin{array}{l}1.4 \\
7\end{array}$ \\
\hline
\end{tabular}




\section{$7^{\text {th }}$ International Conference On Opportunities and Challenges In MANAGEMENT, ECONOMICS and ACCOUNTING}

18-20 June, 2021

\author{
Brussels, Belgium
}

\section{Regression Results}

Table 7 provides the empirical findings for the two regression models to examine the association between board of directors' characteristics and earnings management. Models 1 to 6 and 7 to 12, in Panel A and B, report the GLS regressions ${ }^{2}$ of independent and control variables on discretionary accruals and abnormal discretionary expense. With square around $.17 \%$ and $.06 \%$, implying that the variables incorporated into the regression model can explain $17 \%$ and $.06 \%$ of the change in the dependent variable (the absolute value of discretionary accruals and abnormal discretionary expense),respectively.

Findings in Panel A and B regarding to $\mathrm{H} 1 \mathrm{a}$ and $\mathrm{H} 1 \mathrm{~b}$ show that the estimated coefficient of Board size (BRDSIZE) has a negative sign, but is statistically insignificant, demonstrating that board size is not able to curb earnings management, which is inconsistent with our H1a and H1b. This result is consistent with the prior studies (Garven 2015; Jaggi et al. 2009; Visvanathan 2008).

With reference to $\mathrm{H} 2 \mathrm{a}$ and $\mathrm{H} 2 \mathrm{~b}$, in line with (Bradbury et al. 2006; Hsu and Wen 2015; Ianniello 2015; Jaggi et al. 2009; Rossi and Cebula 2015), the estimated coefficient of board independence (BRDIND), as presented in Table 7, is found to be insignificant, means that hypothesis $\mathrm{H} 3 \mathrm{a}$ and $\mathrm{H} 3 \mathrm{~b}$ are supported. A possible explanation of these findings may back to that the independence of directors may have no meaty impact due to the inherent associations between the directors and the management, and some time the independence of board members may be only formal (e.g., self-declared) (Ianniello 2015). As stated by Di Pietra et al. (2008, 75), who wrote: "in practice it is rather difficult to classify independent directors as truly independent from management'”

Interestingly, while Panel A in Table 7, shows that the coefficient of CEO Duality (BRDDUAL) is negative and statistically insignificant. Panal B in Table 7, shows the coefficient of BEDDUA is significantly negative. Suggesting that CEO Duality (BRDDUAL) is more effective in construing abnormal level of discretionary expenses than discretionary accruals. Which means that hypothesis $\mathrm{H} 3 \mathrm{a}$ is not supported while hypothesis $\mathrm{H} 3 \mathrm{~b}$ is supported. However, even though no statistically significant association is discovered between BEDDUA and DAC, a negative directional sign of the coefficient is noted. Our findings may support the stewardship theory view which argues that the dual position of CEO and chairman enables management to take autonomous executive actions (Davis et al. 1997).

Furthermore, Panel A and B of Table 7 shows a negative and marginally significant of board meetings (BRDMEET) with both type of earnings management (the absolute value of discretionary accruals and abnormal discretionary expense). Which signifies that the board's meetings mitigate earnings management. Thus, Hypothesis $\mathrm{H} 4 \mathrm{a}$ and $\mathrm{H} 4 \mathrm{~b}$ are accepted. This

\footnotetext{
${ }^{2}$ The Hausman test (1978) is undertaken to decide between the fixed effects (OLS) and random effects (GLS) as an alternative panel data method. The Hausman test proposes the random effect model as a superior option.
} 


\title{
$7^{\text {th }}$ International Conference On Opportunities
}

and Challenges In MANAGEMENT,

ECONOMICS and ACCOUNTING

\author{
18-20 June, 2021 \\ Brussels, Belgium
}

result is consistent with previous literature in US and developing countries (Chouaibi et al. 2016; González and García-Meca 2014; Vafeas 1999; Xie et al. 2003).

Finally, the coefficients of gender diversity (GENDIV) are insignificant in both Panel $\mathrm{A}$ and Panel B of Table 7. This indicates that gender diversity (GENDIV) is not likely to contribute to a lower magnitude of earnings management. Hence, Hypothesis H5a and H5b are rejected. As a potential explanation of such a result, gender diversity has not sufficiently legislated on CG code in MENA regions. It also still represents a relatively low proportion compared with their male counterparts. This outcome supports the conclusions of Brammer et al. (2007) that gender diversity is very constrained, and that diversity is fairly slight marked in executive positions.

\section{Robustness check}

\subsection{Controlling for "Big Bath" Effect}

Big bath is a managerial strategy that aims to dispose of all the bad news in one go, which will allow the raising of earnings in future years (Jones 2011; Levitt Jr 1998; McKEE 2005). Following (Frankel et al. 2002; Srinidhi and Gul 2007), We employ a dummy variable (LOSS) that takes the number of one if the firm incurs a loss and zero otherwise, to control of "big bath" type charges that could mean poor accrual quality. Healy (1985) contend that firms may tend to use a "big bath" when they fail to meet earnings targets. This variable is also applied by other scholars to control for directors ${ }^{\text {ee }}$ motivation to evade earnings decreases and losses (Chen et al. 2005). Our results stay unchanged after replicating the analysis with this indicator variable and therefore confirm the outcomes of the main analysis as presented in Table 8. 


\section{$7^{\text {th }}$ International Conference On Opportunities}

and Challenges In MANAGEMENT,

ECONOMICS and ACCOUNTING

\section{8-20 June, $2021 \quad$ Brussels, Belgium}

Table 8 GLS regression results of the board of directors' characteristics and the control variables on earnings management

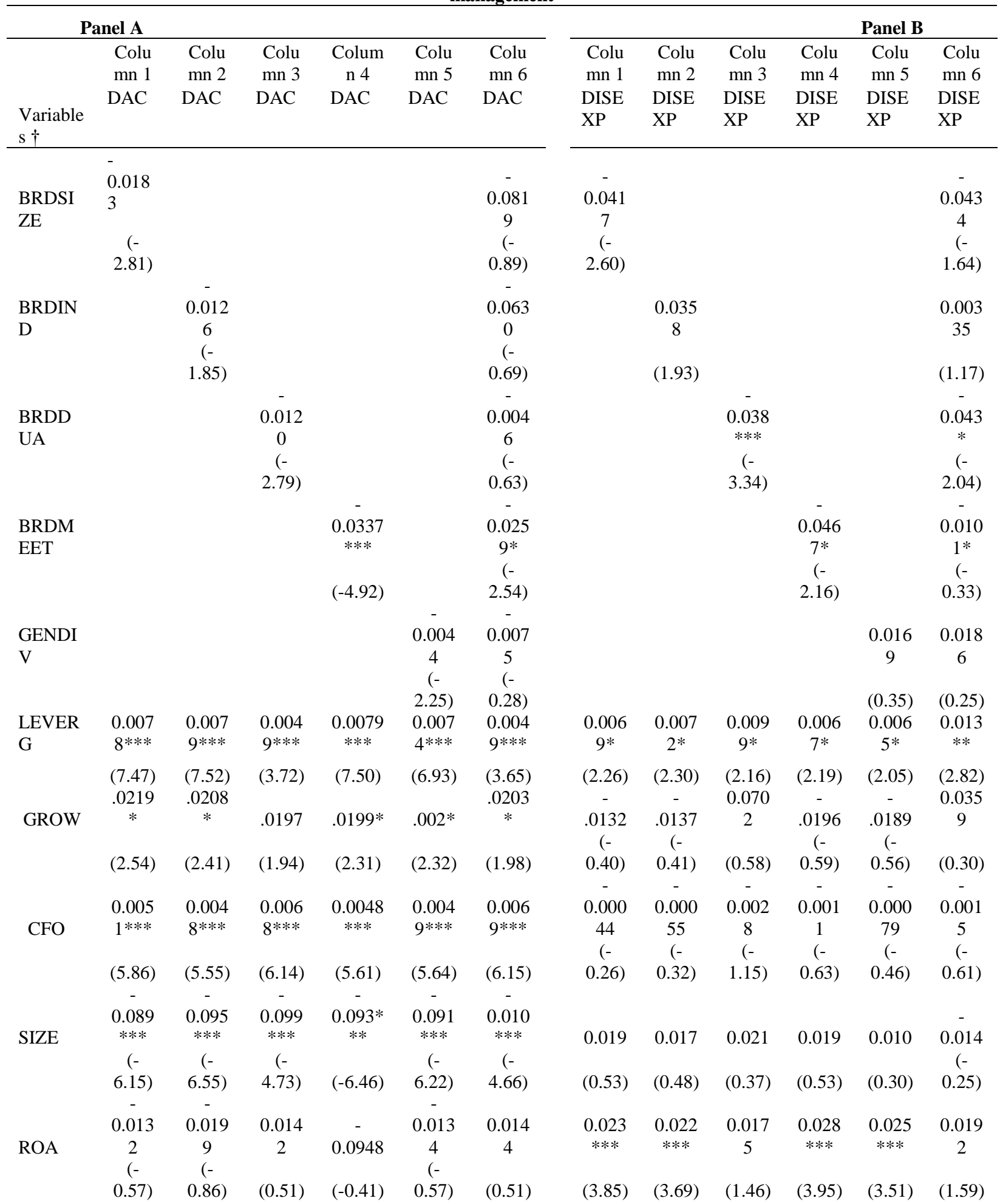




\section{$7^{\text {th }}$ International Conference On Opportunities}

and Challenges In MANAGEMENT, ECONOMICS and ACCOUNTING

\section{8-20 June, $2021 \quad$ Brussels, Belgium}

\begin{tabular}{|c|c|c|c|c|c|c|c|c|c|c|c|c|}
\hline & 0.005 & 0.006 & 0.003 & - & 0.006 & 0.005 & & & & & & 0.091 \\
\hline \multirow[t]{3}{*}{ EPS } & 4 & 3 & 2 & 0.0018 & 2 & 7 & 0.015 & 0.014 & 0.073 & 0.026 & 0.013 & $*$ \\
\hline & $\begin{array}{c}(- \\
0.64)\end{array}$ & $\begin{array}{c}(- \\
0.75)\end{array}$ & $(0.25)$ & $(-0.21)$ & $\begin{array}{c}(- \\
0.74)\end{array}$ & $(0.44)$ & $(0.81)$ & $(0.72)$ & (1.91) & (1.34) & $(0.70)$ & $(2.33)$ \\
\hline & 0.116 & 0.108 & 0.131 & $0.108 *$ & 0.104 & 0.140 & 0.076 & 0.025 & 0.061 & 0.059 & 0.044 & 0.097 \\
\hline \multirow[t]{2}{*}{ _cons } & *** & *** & *** & ** & $* * *$ & *** & $2 *$ & 7 & 7 & $0 *$ & 8 & 5 \\
\hline & (9.43) & $(9.22)$ & $(8.07)$ & (9.48) & (9.26) & (7.62) & $(2.41)$ & $(0.83)$ & (1.36) & $(2.00)$ & (1.49) & $(1.83)$ \\
\hline $\mathrm{N}$ & 915 & 915 & 915 & 915 & 915 & 915 & 915 & 915 & 915 & 915 & 915 & 915 \\
\hline R2 & 0.16 & 0.16 & 0.17 & 0.16 & 0.16 & 0.17 & 0.05 & 0.05 & 0.06 & 0.06 & 0.04 & 0.10 \\
\hline
\end{tabular}


$7^{\text {th }}$ International Conference On Opportunities

and Challenges In MANAGEMENT,

\section{ECONOMICS and ACCOUNTING}

\section{8-20 June, $2021 \quad$ Brussels, Belgium}

Table 8 test of big bath effects

\begin{tabular}{|c|c|c|}
\hline & MODEL 1 & $\begin{array}{l}\text { MODEL } 2 \\
\text { DISFXP }\end{array}$ \\
\hline Variables $\dagger$ & & \\
\hline \multirow{2}{*}{ BRDSIZE } & -0.0770 & -0.0366 \\
\hline & $(-0.84)$ & $(-1.37)$ \\
\hline \multirow{2}{*}{ BRDIND } & -0.0718 & 0.0363 \\
\hline & $(-0.78)$ & $(1.26)$ \\
\hline \multirow{2}{*}{ BRDDUA } & -0.00363 & $-0.0318 *$ \\
\hline & $(-0.49)$ & $(-1.50)$ \\
\hline \multirow{2}{*}{ BRDMEET } & $-0.0241 *$ & $-0.0253 *$ \\
\hline & $(-2.32)$ & $(-0.80)$ \\
\hline \multirow{2}{*}{ GENDIV } & -0.00813 & 0.0206 \\
\hline & $(-0.30)$ & $(0.28)$ \\
\hline \multirow{2}{*}{ LEVERG } & $0.0468 * * *$ & $0.0139 * *$ \\
\hline & $(3.45)$ & $(2.94)$ \\
\hline \multirow[t]{2}{*}{ GROW } & .0196 & 0.0424 \\
\hline & (1.90) & $(0.35)$ \\
\hline \multirow{2}{*}{ CFO } & $0.0670 * * *$ & -0.0225 \\
\hline & (6.03) & $(-0.93)$ \\
\hline \multirow{2}{*}{ SIZE } & 0.00260 & 0.0140 \\
\hline & $(0.85)$ & (1.06) \\
\hline \multirow{2}{*}{ ROA } & $-0.0937 * * *$ & 0.0434 \\
\hline & $(-4.25)$ & $(0.07)$ \\
\hline \multirow{2}{*}{ EPS } & 0.0141 & 0.0699 \\
\hline & $(0.11)$ & (1.87) \\
\hline \multirow[t]{2}{*}{ LOSS } & 0.0658 & -0.0324 \\
\hline & $(0.85)$ & $(-1.29)$ \\
\hline \multirow[t]{2}{*}{ _cons } & $0.132 * * *$ & 0.0861 \\
\hline & (7.06) & (1.59) \\
\hline $\mathrm{R} 2$ & 0.16 & 0.10 \\
\hline $\mathrm{N}$ & 915 & 915 \\
\hline
\end{tabular}

* Significant at the 0.05 level (2-tailed) $\quad * *$ Significant at the 0.01 level (2-tailed) $\quad * * *$ Significant at the 0.001 level (2-tailed).

$\uparrow$ Please see Table 3 for Variable definitions. 


\section{$7^{\text {th }}$ International Conference On Opportunities}

and Challenges In MANAGEMENT,

\section{ECONOMICS and ACCOUNTING}

\section{8-20 June, $2021 \quad$ Brussels, Belgium}

\subsection{Sub-models of the original model.}

Following (Bajra and Čadež 2018), We repeat our main analysis by including two submodels for the two original models (accrual and real - based earnings management). Model 1(3) only includes control variables and is presented in Panel A of Table 9 (Panel B of Table 9). Model 2 (4) contains variables of the board of directors characteristics without control variables and is displayed in Panel A of Table 9 (Panel B of Table 9). Again, the findings remain similar to those reported in Table 7.

Table 9 Sub-models of the original model.

\begin{tabular}{|c|c|c|c|c|}
\hline & \multicolumn{2}{|c|}{ Panel A } & \multicolumn{2}{|c|}{ Panel B } \\
\hline \multirow[b]{2}{*}{ Variables $\uparrow$} & MODEL 1 & MODEL 2 & MOI & MODEL 4 \\
\hline & DAC & DAC & DISEXP & DISEXP \\
\hline \multirow{2}{*}{ BRDSIZE } & & -0.0549 & & -0.0255 \\
\hline & & $(-0.60)$ & & $(-1.02)$ \\
\hline \multirow{2}{*}{ BRDIND } & & -0.0426 & & 0.0379 \\
\hline & & $(-0.47)$ & & (1.38) \\
\hline \multirow{2}{*}{ BRDDUA } & & 0.0564 & & $-0.0278 *$ \\
\hline & & $(0.79)$ & & $(-1.45)$ \\
\hline \multirow{2}{*}{ BRDMEET } & & $-0.0324 * *$ & & $-0.0239^{*}$ \\
\hline & & $(-3.28)$ & & $(-0.85)$ \\
\hline \multirow{2}{*}{ GENDIV } & & -0.0113 & & 0.0373 \\
\hline & & $(-0.43)$ & & $(0.54)$ \\
\hline \multirow{2}{*}{ LEVERG } & $0.0801 * * *$ & & 0.0489 & \\
\hline & (7.89) & & (1.65) & \\
\hline \multirow{2}{*}{ GROW } & $.0208 *$ & & -.0170 & \\
\hline & $(2.44)$ & & $(-0.51)$ & \\
\hline \multirow{2}{*}{$\mathrm{CFO}$} & $0.0477 * * *$ & & -0.0127 & \\
\hline & $(5.88)$ & & $(-0.78)$ & \\
\hline \multirow{2}{*}{ SIZE } & $-0.0875 * * *$ & & 0.0143 & \\
\hline & $(-6.30)$ & & $(0.41)$ & \\
\hline \multirow{2}{*}{ ROA } & -0.0111 & & $0.0264 * * *$ & \\
\hline & $(-0.49)$ & & (3.79) & \\
\hline \multirow{2}{*}{ EPS } & -0.0116 & & 0.0137 & \\
\hline & $(-1.48)$ & & $(0.08)$ & \\
\hline \multirow{2}{*}{ _cons } & $0.0971 * * *$ & $0.0791 * * *$ & 0.0477 & $0.115 * * *$ \\
\hline & (9.01) & (8.57) & (1.66) & (4.19) \\
\hline \multirow{2}{*}{$\begin{array}{l}\mathrm{R} 2 \\
\mathrm{~N}\end{array}$} & 0.16 & 0.04 & 0.04 & 0.04 \\
\hline & 915 & 915 & 915 & 915 \\
\hline
\end{tabular}




\title{
$7^{\text {th }}$ International Conference On Opportunities and Challenges In MANAGEMENT, ECONOMICS and ACCOUNTING
}

\author{
18-20 June, 2021 \\ Brussels, Belgium
}

\subsection{Heteroscedasticity and autocorrelation checks}

The data for our sample is subjected to the Breush-Pagan test to confirm whether or not heteroscedasticity exists, and the Durbin-Watson test for autocorrelation. The Breush-Pagan test findings were a significant $p$-value at $p<0.01$ for both models, which signal the presence of heteroscedasticity issues. Robust Standard Errors is used as a common approach to correct heteroscedasticity. Panel A of Table 10 shows that the results of robust regressions are relatively consistent with the GLS regression presented in the main findings (Table 7). The Durbin-Watson test for autocorrelation reports a no statistically significant in both models DAC and DISEXP, $\mathrm{P}=1.2662 ; 3504412$, respectively. Thereby no presence of serial correlation across entities in both models.

\subsection{Endogeneity test}

We recognize that the endogeneity problem may cause a major methodological concern for this type of analysis, thus, any casual inferences drawn from our regression model might be incorrect (Abdallah et al. 2015; Winship and Morgan 1999). In our research, we are knowledgeable of this possibility and endeavor to assure our findings are not consequently extreme.

With this in mind we employ instrumental variables (IV) two-stage regression (2SLS) approach analysis, which corrects for simultaneity, omitted variables, or measurement errors (Cameron and Trivedi 2005). And it employs the lagged values of the endogenous variables as instruments. In the analysis, all board variables are treated as endogenous. The Durbin-WuHausman test conducted for each variable examined under the two board' models to investigate whether there is any endogeneity bias for the independent variables. The Durbin-Wu-Hausman test gives an insignificant p-value with both DAC and DISDAC, consequently proving the absence of endogeneity concerns. As is evident, the results of the two-stage regression (2SLS) in Panel B of Table 10 for both models appear to remain stable and constant compared to the GLS results reported earlier. 


\section{$7^{\text {th }}$ International Conference On Opportunities}

and Challenges In MANAGEMENT,

ECONOMICS and ACCOUNTING

\section{8-20 June, $2021 \quad$ Brussels, Belgium}

Table 10 Heteroscedasticity, autocorrelation checks and Endogeneity test

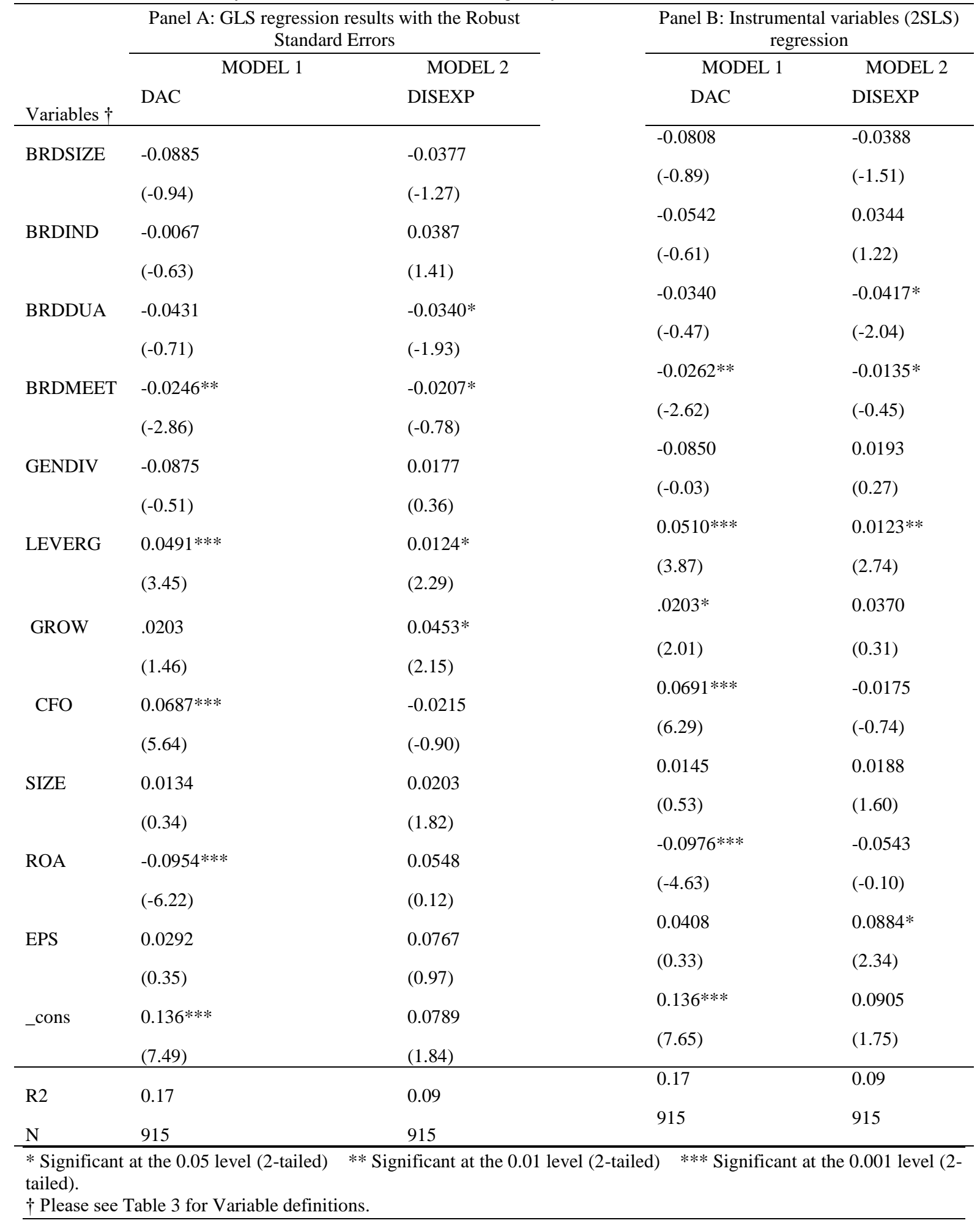




\title{
$7^{\text {th }}$ International Conference On Opportunities and Challenges In MANAGEMENT, ECONOMICS and ACCOUNTING
}

\author{
18-20 June, 2021
}

\author{
Brussels, Belgium
}

\section{Discussion}

This research attempted to examine the role of board of director in mitigating earnings management In the MENA region. The uniqueness of this study lies in its institutional context that differs from the Anglo-Saxon setting. To our knowledge, this is the first study to test the board of directors' characteristics (i.e. size, independence, activity, CEO duality and gender diversity) and accrual and real - based earnings management, after a regulatory frame for CG in the MENA countries. Our findings contribute to related CG research by noting that the relations between board of directors' characteristics and earnings management are affected by national institutional aspects.

Our evidence indicates that board meeting affects earnings management through accruals and real activities manipulation. Besides, the findings show that CEO duality deters earnings management through real activities manipulation more than accruals-based earnings management. Further, the results exhibit that other board characteristics (i.e., size, independence, and gender diversity) have no significant impact on earnings management practices. These results illustrate that despite the intended benefit from enactment governance codes in MENA regain, the CG mechanisms (i,e,. board of directors) are still contributed little value.

Bao and Lewellyn (2017) and Daniel et al. (2011) indicate that CG reforms may be ineffective because they are unsuitable to the emerging countries' institutional environment or lack of social legitimacy. In MENA regain, there is highly concentrated ownership (Fan and Wong 2002); weak enforcement of the rule of law, less transparent disclosure of financial reporting (Dharwadkar et al. 2000; Mitton 2002; Young et al. 2008). In addition, weak investor protection. Consequently, this drives to the failure of CG mechanisms and severe earnings management. Meanwhile, compared to Anglo-Saxon countries, the adoption of good CG practices in developing markets is mainly driven by international demands rather than a genuine spirit of good CG (Young et al. 2008; Goh and Rasli 2014). And "exist only on paper" (Amico 2014). As a result, the board of directors lacks a real role, which would justify its ineffectiveness as a monitoring instrument.

Furthermore, the appointment of the independent directors in the board has generally been seen as a source of expertise to advise management rather than providing them with the monitoring responsibility and controlling managerial activities (Anderson and Reeb 2004; Gomez-Mejia et al. 2011; Goh and Rasli 2014). Finally, as noted by Waweru and Prot (2018) the "comply or explain" approach can be behind this fact since many companies tend to adopt a "box ticking" behavior and limit themselves to pointing out a compliance with the recommendations of the $\mathrm{CG}$ codes that, in many cases, does not reflect the reality.

\section{Conclusion}

The main motive of this research is to test whether the board of director's characteristics affect accrual and real - based earnings management as measured by discretionary accruals and 


\title{
$7^{\text {th }}$ International Conference On Opportunities and Challenges In MANAGEMENT, ECONOMICS and ACCOUNTING
}

\author{
18-20 June, 2021 \\ Brussels, Belgium
}

abnormal discretionary expense, respectively, in the MENA. The study employs a dataset that includes 915 firms -year observations from 10 countries, covering a period of eleven years from 2007 to 2017 . We found that board meeting is negatively associated with earnings management, while CEO duality can deter only real earnings management. In addition, other board characteristics such as board size, board independence, and gender diversity are not related to earnings management. Therefore, our results suggest, the CG mechanisms in MENA regain i.e., the board of directors are not able to provide adequate monitoring and /or are not immersed in monitoring actions with regards to improving CG and financial reporting quality. This conclusion introduces new insights into related $\mathrm{CG}$ research, especially in developing nations.

The main implication of the results above is that the formal presence of the board of directors within a firm is just a necessary, but not enough condition for earnings quality In MENA countries. Thus, our results motivate governments and regulators in the MENA area and other emerging countries to review and amend the governance code whenever needed, in particular, "comply or explain approach." Further, for managers and corporations, our evidence recommends that they may be able to prevent earnings management by holding frequency meetings. Finally, for scholars, our research may be helpful to give him a comprehensive and updated picture of the relation between the board of directors and earnings management in the MENA area and developing countries as well.

Like any other research in this domain, the current study suffers from a number of limitations. First, our findings are subject to measurement errors of earnings management. Therefore, future investigations may use other representations of earnings management, such as related party transactions and direct asset misappropriation. Thus, they may be able to provide a further understanding of how CG mechanisms affect earnings management in developing economics. Second, the measurement of some variables may not be consistent among countries (MENA countries Vs. Jordan), where every country utilize different standards to define variables (Board meeting). Hence, in future studies, it would be interesting to apply the same criteria. Third, our findings may be somewhat limited by data availability. We have been unable to incorporate other vital variables that may affect earnings management, such as auditor size, audit fees, political connection, audit committee's characteristics, and ownership structure. Thus, as more appropriate data becomes accessible, future work may attempt to extend our results by controlling these factors. Finally, to make further progress, future research may use other approaches to explore this association by conducting qualitative research methods such as interviews or grounded theory since this study conducts quantitative analysis. 


\section{$7^{\text {th }}$ International Conference On Opportunities}

and Challenges In MANAGEMENT,

ECONOMICS and ACCOUNTING

\section{8-20 June, $2021 \quad$ Brussels, Belgium}

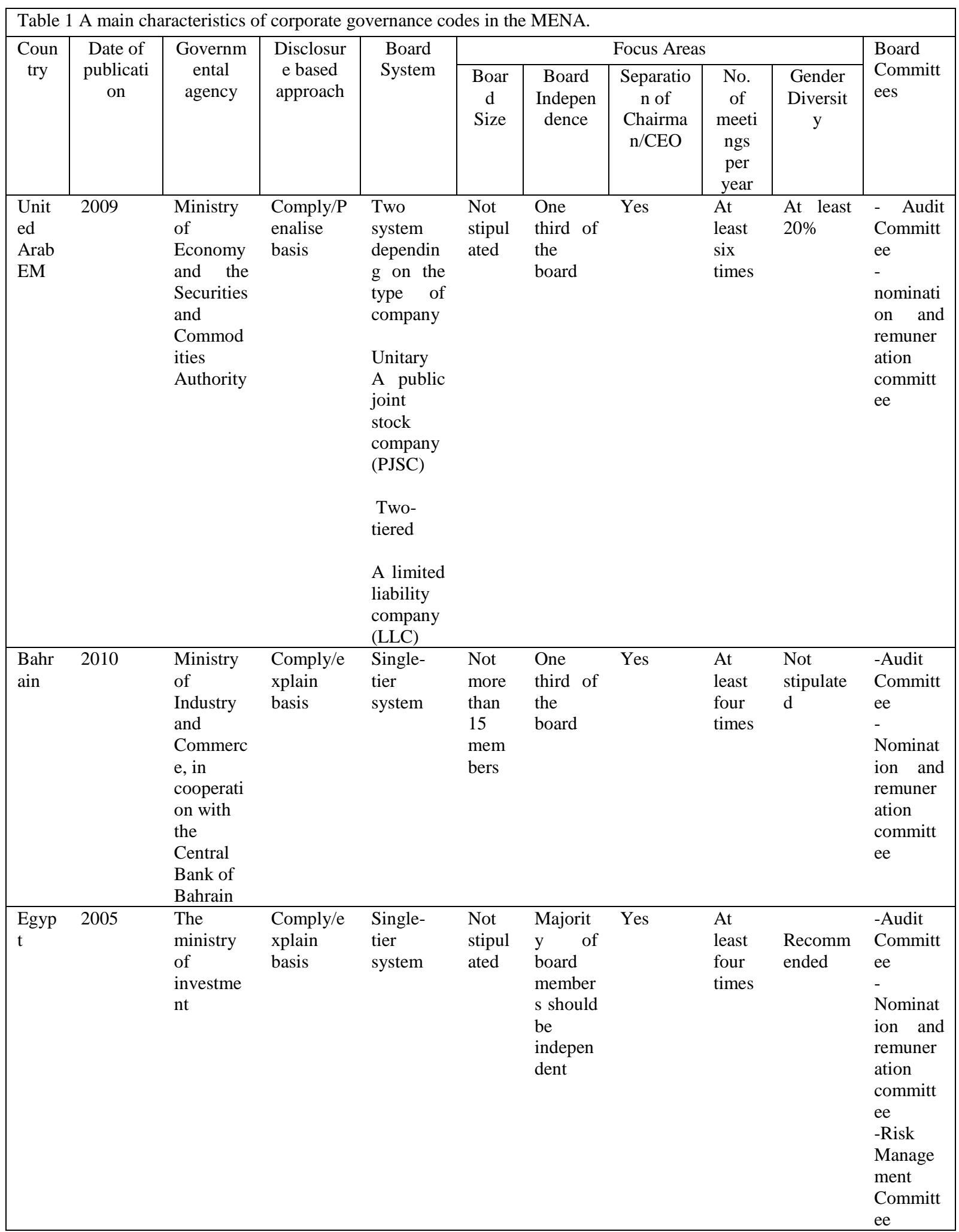




\section{$7^{\text {th }}$ International Conference On Opportunities}

and Challenges In MANAGEMENT, ECONOMICS and ACCOUNTING

Governa nce Committ ee

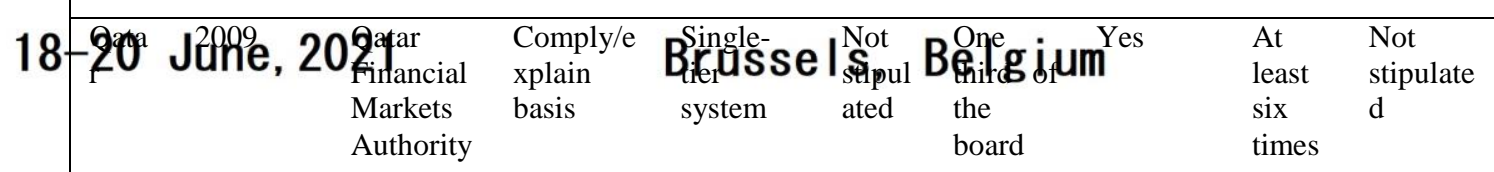

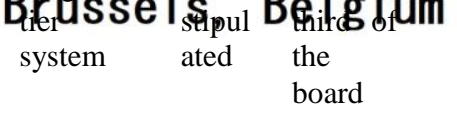

-Audit

Committ

ee
Nominat ion and remuner ation

committ

ee

\begin{tabular}{|c|c|c|c|c|c|c|c|c|c|c|}
\hline $\begin{array}{l}\text { Saud } \\
\text { i } \\
\text { Arab } \\
\text { ia }\end{array}$ & $\begin{array}{l}2006 \\
\text { (amende } \\
\mathrm{d} \text { in } \\
2010 \text { ) }\end{array}$ & $\begin{array}{l}\text { the } \\
\text { Capital } \\
\text { Market } \\
\text { Authority }\end{array}$ & $\begin{array}{l}\text { Comply/e } \\
\text { xplain } \\
\text { basis }\end{array}$ & $\begin{array}{l}\text { Single- } \\
\text { tier } \\
\text { system }\end{array}$ & $\begin{array}{l}\text { Not } \\
\text { less } \\
\text { than } \\
\text { three, } \\
\text { not } \\
\text { more } \\
\text { than } \\
11 \\
\text { mem } \\
\text { bers }\end{array}$ & $\begin{array}{l}\text { A } \\
\text { minimu } \\
\mathrm{m} \quad \text { of } \\
\text { one- } \\
\text { third } \\
\text { indepen } \\
\text { dent } \\
\text { director } \\
\mathrm{s} \text {, } \\
\text { or two } \\
\text { member } \\
\mathrm{s} \text {, } \\
\text { whiche } \\
\text { ver is } \\
\text { greater }\end{array}$ & Yes & $\begin{array}{l}\text { At } \\
\text { least } \\
\text { four } \\
\text { times }\end{array}$ & $\begin{array}{l}\text { Not } \\
\text { stipulate } \\
\text { d }\end{array}$ & $\begin{array}{l}\text {-Audit } \\
\text { committ } \\
\text { ee } \\
- \\
\text { Nominat } \\
\text { ions and } \\
\text { rewards } \\
\text { committ } \\
\text { ee } \\
\text {-Risk } \\
\text { Manage } \\
\text { ment } \\
\text { Committ } \\
\text { ee }\end{array}$ \\
\hline $\begin{array}{l}\text { Kuw } \\
\text { ait }\end{array}$ & 2010 & $\begin{array}{l}\text { Capital } \\
\text { Standards } \\
\text { Rating } \\
\text { Agency }\end{array}$ & $\begin{array}{l}\text { Comply/e } \\
\text { xplain } \\
\text { basis }\end{array}$ & $\begin{array}{l}\text { Single- } \\
\text { tier } \\
\text { system }\end{array}$ & $\begin{array}{l}\text { Not } \\
\text { stipul } \\
\text { ated }\end{array}$ & $\begin{array}{l}\text { A } \\
\text { minimu } \\
\mathrm{m} \text { of } \\
\text { one- } \\
\text { third } \\
\text { indepen } \\
\text { dent } \\
\text { director } \\
\text { s, or two } \\
\text { member } \\
\text { s, } \\
\text { whiche } \\
\text { ver is } \\
\text { greater. } \\
\text { One- } \\
\text { third } \\
\text { should } \\
\text { be } \\
\text { indepen } \\
\text { dent in } \\
\text { compan } \\
\text { ies with } \\
\text { a } \\
\text { controll } \\
\text { ing } \\
\text { shareho } \\
\text { lder }\end{array}$ & Yes & $\begin{array}{l}\text { At } \\
\text { least } \\
\text { four } \\
\text { times }\end{array}$ & $\begin{array}{l}\text { Not } \\
\text { stipulate } \\
\text { d }\end{array}$ & $\begin{array}{l}\text {-Audit } \\
\text { Committ } \\
\text { ee } \\
- \\
\text { Nominat } \\
\text { ion and } \\
\text { remuner } \\
\text { ation } \\
\text { committ } \\
\text { ee } \\
\text {-Risk } \\
\text { Manage } \\
\text { ment } \\
\text { Committ } \\
\text { ee } \\
- \\
\text { Governa } \\
\text { nce } \\
\text { Committ } \\
\text { ee }\end{array}$ \\
\hline $\begin{array}{l}\text { Oma } \\
\mathrm{n}\end{array}$ & $\begin{array}{l}2002(\mathrm{~A} \\
\text { mended } \\
\text { and } \\
\text { replaced } \\
\text { in 2003) }\end{array}$ & $\begin{array}{l}\text { Capital } \\
\text { market } \\
\text { authority( } \\
\text { CMA) }\end{array}$ & $\begin{array}{l}\text { Comply/e } \\
\text { xplain } \\
\text { basis }\end{array}$ & $\begin{array}{l}\text { Single- } \\
\text { tier } \\
\text { system }\end{array}$ & $\begin{array}{l}\text { Not } \\
\text { stipul } \\
\text { ated }\end{array}$ & $\begin{array}{l}\text { One } \\
\text { third of } \\
\text { the } \\
\text { board }\end{array}$ & Yes & $\begin{array}{l}\text { At } \\
\text { least } \\
\text { four ti } \\
\text { mes }\end{array}$ & $\begin{array}{l}\text { Not } \\
\text { stipulate } \\
\text { d }\end{array}$ & $\begin{array}{l}\text {-Audit } \\
\text { Committ } \\
\text { ee } \\
\text { - } \\
\text { nominati } \\
\text { on and } \\
\text { remuner } \\
\text { ation }\end{array}$ \\
\hline
\end{tabular}


$7^{\text {th }}$ International Conference On Opportunities

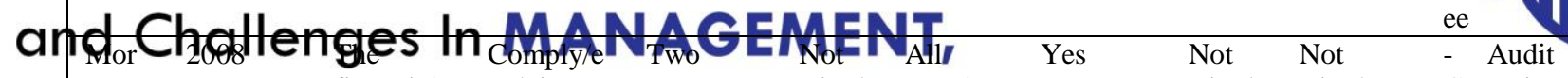

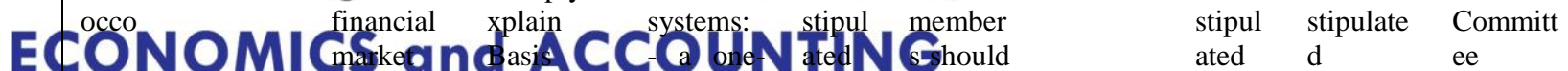
ECONOMI authority

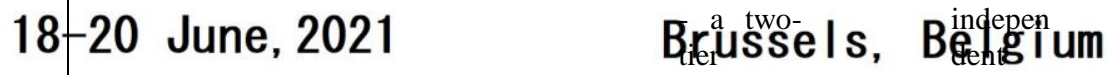

Compen

sation

and

Nominat

ions

Committ

\begin{tabular}{|c|c|c|c|c|c|c|c|c|c|c|}
\hline \multirow[b]{2}{*}{$\begin{array}{l}\text { Turk } \\
\text { ey }\end{array}$} & & & & & & & & & & \\
\hline & 2003 & $\begin{array}{l}\text { Capital } \\
\text { Market } \\
\text { Board of } \\
\text { Turkey }\end{array}$ & $\begin{array}{l}\text { Comply/e } \\
\text { xplain } \\
\text { basis }\end{array}$ & $\begin{array}{l}\text { Single- } \\
\text { tier } \\
\text { system }\end{array}$ & $\begin{array}{l}\text { Not } \\
\text { less } \\
\text { than } \\
\text { five } \\
\text { mem } \\
\text { ber } \\
\text { in } \\
\text { any } \\
\text { case }\end{array}$ & $\begin{array}{l}\text { A } \\
\text { minimu } \\
\mathrm{m} \text { of } \\
\text { one- } \\
\text { third } \\
\text { indepen } \\
\text { dent } \\
\text { director } \\
\mathrm{s} \text {, } \\
\text { or two } \\
\text { member } \\
\mathrm{s} \text {, } \\
\text { whiche } \\
\text { ver is } \\
\text { greater }\end{array}$ & Yes & $\begin{array}{l}\text { As } \\
\text { often } \\
\text { as } \\
\text { intern } \\
\text { al } \\
\text { operat } \\
\text { ions } \\
\text { of the } \\
\text { comp } \\
\text { any } \\
\text { requir } \\
\text { e. }\end{array}$ & $\begin{array}{l}\text { not less } \\
\text { than } \\
25 \%\end{array}$ & $\begin{array}{l}\text { - Audit } \\
\text { Committ } \\
\text { ee } \\
\text { - } \\
\text { nominati } \\
\text { on and } \\
\text { remuner } \\
\text { ation } \\
\text { committ } \\
\text { ee } \\
\text { - } \\
\text { Governa } \\
\text { nce } \\
\text { Committ } \\
\text { ee }\end{array}$ \\
\hline $\begin{array}{l}\text { Jorda } \\
\mathrm{n}\end{array}$ & $\begin{array}{l}2009 \\
\text { (updated } \\
\text { in 2017) }\end{array}$ & $\begin{array}{l}\text { The } \\
\text { Jordanian } \\
\text { Securities } \\
\text { Commiss } \\
\text { ion (JSC) }\end{array}$ & $\begin{array}{l}\text { Comply/e } \\
\text { xplain } \\
\text { basis }\end{array}$ & $\begin{array}{l}\text { Single- } \\
\text { tier } \\
\text { system }\end{array}$ & $\begin{array}{l}\text { Not } \\
\text { less } \\
\text { than } \\
\text { five, } \\
\text { not } \\
\text { more } \\
\text { than } \\
13 \\
\text { mem } \\
\text { bers }\end{array}$ & $\begin{array}{l}\text { One } \\
\text { third of } \\
\text { the } \\
\text { board }\end{array}$ & Yes & $\begin{array}{l}\text { At } \\
\text { least } \\
\text { six } \\
\text { times }\end{array}$ & $\begin{array}{l}\text { Not } \\
\text { stipulate } \\
\text { d }\end{array}$ & $\begin{array}{l}\text {-Audit } \\
\text { Committ } \\
\text { ee } \\
\text { - } \\
\text { Nominat } \\
\text { ions and } \\
\text { Compen } \\
\text { sations } \\
\text { Committ } \\
\text { ee }\end{array}$ \\
\hline
\end{tabular}

\section{References}

Abdallah, W., M. Goergen, and N. O'Sullivan. 2015. Endogeneity: How failure to correct for it can cause wrong inferences and some remedies. British Journal of Management 26 (4):791-804.

Abdul Rahman, R., and F. M. Ali. 2006. Board, audit committee, culture and earnings management: Malaysian evidence. Managerial Auditing Journal 21 (7):783-804.

Abdullah, S. N., and K. N. I. K. Ismail. 2016. Women directors, family ownership and earnings management in Malaysia. Asian Review of Accounting 24 (4):525-550.

Adams, R. B., and D. Ferreira. 2009. Women in the boardroom and their impact on governance and performance. Journal of Financial Economics 94 (2):291-309.

Al-Ajmi, J. 2009. Audit firm, corporate governance, and audit quality: Evidence from Bahrain. Advances in Accounting 25 (1):64-74.

Al-Bassam, W. M., C. G. Ntim, K. K. Opong, and Y. Downs. 2018. Corporate boards and ownership structure as antecedents of corporate governance disclosure in Saudi Arabian publicly listed corporations. Business \& Society 57 (2):335-377. 


\title{
$7^{\text {th }}$ International Conference On Opportunities and Challenges In MANAGEMENT, ECONOMICS and ACCOUNTING
}

\author{
18-20 June, 2021 \\ Brussels, Belgium
}

Almarayeh, T. S. S. 2019. Restricting earnings management through corporate governance mechanisms: evidence from Jordan.

Alves, S. 2012. Executive stock options and earnings management in the portuguese listed companies. Revista de Contabilidad 15 (2):211-235.

Alzoubi, E. S. S. 2016. Audit quality and earnings management: evidence from Jordan. Journal of Applied Accounting Research 17 (2):170-189.

Amico, A. 2014. Corporate Governance Enforcement in the Middle East and North Africa: Evidence and Priorities. OECD Corporate Governance Working Papers, No. 15, OECD

Publishing, Paris. http://dx.doi.org/10.1787/5jxws6scxg7c-en. Accessed 11 March 2019.

Ammann, M., D. Oesch, and M. M. Schmid. 2011. Corporate governance and firm value: International evidence. Journal of Empirical Finance 18 (1):36-55.

Anderson, R. C., and D. M. Reeb. 2004. Board composition: Balancing family influence in S\&P 500 firms. Administrative science quarterly 49 (2):209-237.

Arun, T. G., Y. E. Almahrog, and Z. A. Aribi. 2015. Female directors and earnings management: Evidence from UK companies. International Review of Financial Analysis 39:137-146.

Ashari, N., H. C. Koh, S. L. Tan, and W. H. Wong. 1994. Factors affecting income smoothing among listed companies in Singapore. Accounting and Business Research 24 (96):291301.

Badertscher, B. A. 2011. Overvaluation and the choice of alternative earnings management mechanisms. The accounting review 86 (5):1491-1518.

Baek, J.-S., J.-K. Kang, and K. S. Park. 2004. Corporate governance and firm value: Evidence from the Korean financial crisis. Journal of Financial Economics 71 (2):265-313.

Bajra, U., and S. Čadež. 2018. Audit committees and financial reporting quality: The 8th EU Company Law Directive perspective. Economic Systems 42 (1):151-163.

Bao, S. R., and K. B. Lewellyn. 2017. Ownership structure and earnings management in emerging markets-An institutionalized agency perspective. International Business Review 26 (5):828-838.

Beasley, M. S. 1996. An empirical analysis of the relation between the board of director composition and financial statement fraud. Accounting review:443-465.

Ben-Hassoun, A., C. Aloui, and H. Ben-Nasr. 2018. Demand for audit quality in newly privatized firms in MENA region: Role of internal corporate governance mechanisms audit. Research in International Business and Finance 45:334-348.

Bennouri, M., T. Chtioui, H. Nagati, and M. Nekhili. 2018. Female board directorship and firm performance: What really matters? Journal of Banking \& Finance 88:267-291.

Bergstresser, D., and T. Philippon. 2006. CEO incentives and earnings management. Journal of Financial Economics 80 (3):511-529.

Berkowitz, D., K. Pistor, and J.-F. Richard. 2003. Economic development, legality, and the transplant effect. European economic review 47 (1):165-195.

Bradbury, M., Y. T. Mak, and S. Tan. 2006. Board characteristics, audit committee characteristics and abnormal accruals. Pacific accounting review 18 (2):47-68. 


\title{
$7^{\text {th }}$ International Conference On Opportunities and Challenges In MANAGEMENT, ECONOMICS and ACCOUNTING
}

\author{
18-20 June, 2021 \\ Brussels, Belgium
}

Brammer, S., A. Millington, and S. Pavelin. 2007. Gender and ethnic diversity among UK corporate boards. Corporate Governance: An International Review 15 (2):393-403.

BRC, B. R. C. 1999. Report and recommendations of Blue Ribbon Committee on improving the effectiveness of corporate audit committees, New York Stock Exchange and National Association of Securities Dealers: New York.

Brennan, N., and M. McDermott. 2004. Alternative perspectives on independence of directors. Corporate Governance: An International Review 12 (3):325-336.

Brickley, J. A., J. L. Coles, and G. Jarrell. 1997. Leadership structure: Separating the CEO and chairman of the board. Journal of Corporate Finance 3 (3):189-220.

Cadbury Report. 1992. The Report of the committee on the financial aspects of corporate governance. Gee Ltd (Professional Publishing Ltd): London.

Cameron, A. C., and P. K. Trivedi. 2005. Microeconometrics: methods and applications: Cambridge university press.

Carcello, J. V., and A. L. Nagy. 2004. Audit firm tenure and fraudulent financial reporting. Auditing: A Journal of Practice \& Theory 23 (2):55-69.

Chang, J. C., and H.-L. Sun. 2009. Crossed-listed foreign firms' earnings informativeness, earnings management and disclosures of corporate governance information under SOX. The International Journal of Accounting 44 (1):1-32.

Chen, G., M. Firth, D. N. Gao, and O. M. Rui. 2006. Ownership structure, corporate governance, and fraud: Evidence from China. Journal of Corporate Finance 12 (3):424-448.

Chen, K. Y., K.-L. Lin, and J. Zhou. 2005. Audit quality and earnings management for Taiwan IPO firms. Managerial Auditing Journal 20 (1):86-104.

Chi, C. W., K. Hung, H. W. Cheng, and P. T. Lieu. 2015. Family firms and earnings management in Taiwan: Influence of corporate governance. International Review of Economics \& Finance 36:88-98.

Chi, J., J. Liao, and X. Chen. 2016. Politically connected CEOs and earnings management: evidence from China. Journal of the Asia Pacific Economy 21 (3):397-417.

Ching, K. M., M. Firth, and O. M. Rui. 2006. Earnings management, corporate governance and the market performance of seasoned equity offerings in Hong Kong. Journal of Contemporary Accounting \& Economics 2 (1):73-98.

Chouaibi, J., M. Harres, and N. B. Brahim. 2016. The Effect of Board Director's Characteristics on Real Earnings Management: Tunisian-Listed Firms. Journal of the Knowledge Economy 9 (3):999-1013.

Chtourou, S. M., J. Bedard, and L. Courteau. 2001. Corporate governance and earnings management. Working Paper,Retrieved from SSRN: http://papers.ssrn.com/abstract=275053.

Cohen, D. A., and P. Zarowin. 2010. Accrual-based and real earnings management activities around seasoned equity offerings. Journal of accounting and economics 50 (1):2-19.

Conger, J. A., D. Finegold, and E. E. Lawler. 1998. Appraising boardroom performance. Harvard business review 76:136-164. 


\title{
$7^{\text {th }}$ International Conference On Opportunities and Challenges In MANAGEMENT, ECONOMICS and ACCOUNTING
}

\author{
18-20 June, 2021 \\ Brussels, Belgium
}

Daily, C. M., D. R. Dalton, and A. A. Cannella. 2003. Corporate governance: Decades of dialogue and data. Academy of management review 28 (3):371-382.

Daniel, S. J., J. K. Cieslewicz, and T. C. Pearson. 2011. State regulation's significant impact on corporate governance practices, earnings management, and disclosure. Asia-Pacific Journal of Accounting \& Economics 18 (2):105-124.

Davidson, R., J. Goodwin- Stewart, and P. Kent. 2005. Internal governance structures and earnings management. Accounting \& Finance 45 (2):241-267.

Davis, J. H., F. D. Schoorman, and L. Donaldson. 1997. Toward a stewardship theory of management. Academy of management review 22 (1):20-47.

Debnath, N., B. Patnaik, and I. Satpathy. 2019. Female directorship and real earnings management in Bangladesh: Towards an analytical assessment. Management Science Letters 9 (11):1723-1740.

Dechow, P. M., R. G. Sloan, and A. P. Sweeney. 1995. Detecting earnings management. Accounting review 70 (2):193-225.

1996. Causes and consequences of earnings manipulation: An analysis of firms subject to enforcement actions by the SEC. Contemporary Accounting Research 13 (1):1-36.

Dharwadkar, B., G. George, and P. Brandes. 2000. Privatization in emerging economies: An agency theory perspective. Academy of management review 25 (3):650-669.

Di Pietra, R., C. A. Grambovas, I. Raonic, and A. Riccaboni. 2008. The effects of board size and 'busy'directors on the market value of Italian companies. Journal of Management \& Governance 12 (1):73-91.

Elghuweel, M. I., C. G. Ntim, K. K. Opong, and L. Avison. 2017. Corporate governance, Islamic governance and earnings management in Oman: A new empirical insights from a behavioural theoretical framework. Journal of Accounting in Emerging Economies 7 (2):190-224.

Fan, J. P., and T. J. Wong. 2002. Corporate ownership structure and the informativeness of accounting earnings in East Asia. Journal of accounting and economics 33 (3):401-425.

Forbes, D. P., and F. J. Milliken. 1999. Cognition and corporate governance: Understanding boards of directors as strategic decision-making groups. Academy of management review 24 (3):489-505.

Frankel, R. M., M. F. Johnson, and K. K. Nelson. 2002. The relation between auditors' fees for nonaudit services and earnings management. The accounting review 77 (s-1):71-105.

Franz, D. R., H. R. HassabElnaby, and G. J. Lobo. 2014. Impact of proximity to debt covenant violation on earnings management. Review of Accounting Studies 19 (1):473-505.

Garven, S. 2015. The effects of board and audit committee characteristics on real earnings management: Do boards and audit committees play a role in its promotion or constraint? Academy of Accounting and Financial Studies Journal 19 (1):67.

Gavious, I., E. Segev, and R. Yosef. 2012. Female directors and earnings management in hightechnology firms. Pacific accounting review 24 (1):4-32. 


\title{
$7^{\text {th }}$ International Conference On Opportunities and Challenges In MANAGEMENT, ECONOMICS and ACCOUNTING
}

\author{
18-20 June, 2021 \\ Brussels, Belgium
}

Gebhardt, G. u., and Z. Novotny- Farkas. 2011. Mandatory IFRS adoption and accounting quality of European banks. Journal of Business Finance \& Accounting 38 (3- 4):289333.

Ghosh, A., A. Marra, and D. Moon. 2010. Corporate boards, audit committees, and earnings management: pre- and post- SOX evidence. Journal of Business Finance \& Accounting 37 (9- 10):1145-1176.

Goh, C. F., and A. Rasli. 2014. CEO duality, board independence, corporate governance and firm performance in family firms: Evidence from the manufacturing industry in Malaysia. Asian Business \& Management 13 (4):333-357.

Gomez-Mejia, L. R., C. Cruz, P. Berrone, and J. De Castro. 2011. The bind that ties: Socioemotional wealth preservation in family firms. Academy of Management Annals 5 (1):653-707.

González, J. S., and E. García-Meca. 2014. Does corporate governance influence earnings management in Latin American markets? Journal of Business Ethics 121 (3):419-440.

Gul, F. A., B. Srinidhi, and A. C. Ng. 2011. Does board gender diversity improve the informativeness of stock prices? Journal of accounting and economics 51 (3):314-338.

Habbash, M., and S. Alghamdi. 2017. Audit quality and earnings management in less developed economies: the case of Saudi Arabia. Journal of Management \& Governance 21 (2):351-373.

Healy, P. M. 1985. The effect of bonus schemes on accounting decisions. Journal of accounting and economics 7 (1-3):85-107.

Healy, P. M., and J. M. Wahlen. 1999. A review of the earnings management literature and its implications for standard setting. Accounting Horizons 13 (4):365-383.

Herring, C. 2009. Does diversity pay?: Race, gender, and the business case for diversity. American Sociological Review 74 (2):208-224.

Hsiao, C. 2007. Panel data analysis — advantages and challenges. Test 16 (1):1-22.

Hsiao, C., D. C. Mountain, and K. H. Illman. 1995. A Bayesian integration of end-use metering and conditional-demand analysis. Journal of Business \& Economic Statistics 13 (3):315-326.

Hsu, M.-F., and S.-Y. Wen. 2015. The influence of corporate governance in Chinese companies on discretionary accruals and real earnings management. Asian Economic and Financial Review 5 (3):391-406.

Ianniello, G. 2015. The effects of board and auditor independence on earnings quality: evidence from Italy. Journal of Management \& Governance 19 (1):229-253.

Iatridis, G. E. 2012. Audit quality in common-law and code-law emerging markets: evidence on earnings conservatism, agency costs and cost of equity. Emerging Markets Review 13 (2):101-117.

Iqbal, S., A. Nawaz, and S. Ehsan. 2019. Financial performance and corporate governance in microfinance: Evidence from Asia. Journal of Asian Economics 60:1-13.

Jaggi, B., and P. Lee. 2002. Earnings management response to debt covenant violations and debt restructuring. Journal of Accounting, Auditing \& Finance 17 (4):295-324. 


\title{
$7^{\text {th }}$ International Conference On Opportunities and Challenges In MANAGEMENT, ECONOMICS and ACCOUNTING
}

\author{
18-20 June, 2021 \\ Brussels, Belgium
}

Jaggi, B., S. Leung, and F. Gul. 2009. Family control, board independence and earnings management: Evidence based on Hong Kong firms. Journal of Accounting and Public Policy 28 (4):281-300.

Jensen, M. C. 1993. The modern industrial revolution, exit, and the failure of internal control systems. The journal of finance 48 (3):831-880.

Jeong, S. W., and J. Rho. 2004. Big Six auditors and audit quality: The Korean evidence. The International Journal of Accounting 39 (2):175-196.

Jha, A. 2013. Earnings management around debt-covenant violations-An empirical investigation using a large sample of quarterly data. Journal of Accounting, Auditing \& Finance 28 (4):369-396.

Jiang, J. X., K. R. Petroni, and I. Y. Wang. 2010. CFOs and CEOs: Who have the most influence on earnings management? Journal of Financial Economics 96 (3):513-526.

Jones, M. 2011. Creative accounting, fraud and international accounting scandals: John Wiley $\&$ Sons.

Kamal Hassan, M. 2012. A disclosure index to measure the extent of corporate governance reporting by UAE listed corporations. Journal of Financial Reporting and Accounting $10(1): 4-33$.

Kang, S.-A., and Y.-S. Kim. 2012. Effect of corporate governance on real activity-based earnings management: Evidence from Korea. Journal of Business Economics and Management 13 (1):29-52.

Kim, J. B., and C. H. Yi. 2006. Ownership structure, business group affiliation, listing status, and earnings management: Evidence from Korea. Contemporary Accounting Research 23 (2):427-464.

Klein, A. 2002. Audit committee, board of director characteristics, and earnings management. Journal of accounting and economics 33 (3):375-400.

Kothari, S., N. Mizik, and S. Roychowdhury. 2015. Managing for the moment: The role of earnings management via real activities versus accruals in SEO valuation. The accounting review 91 (2):559-586.

Krishnan, G. V. 2003. Does Big 6 auditor industry expertise constrain earnings management? Accounting Horizons 17:1-16.

Krishnan, G. V., and L. M. Parsons. 2008. Getting to the bottom line: An exploration of gender and earnings quality. Journal of Business Ethics 78 (1-2):65-76.

Kumar, P., and G. P. Tsetsekos. 1999. The differentiation of'emerging'equity markets. Applied Financial Economics 9 (5):443-453.

La Porta, R., F. Lopez- de- Silanes, A. Shleifer, and R. Vishny. 2002. Investor protection and corporate valuation. The journal of finance 57 (3):1147-1170.

Lemmon, M. L., and K. V. Lins. 2003. Ownership structure, corporate governance, and firm value: Evidence from the East Asian financial crisis. The journal of finance 58 (4):1445-1468.

Levitt Jr, A. 1998. The numbers game. The CPA journal 68 (12):14. 


\title{
$7^{\text {th }}$ International Conference On Opportunities and Challenges In MANAGEMENT, ECONOMICS and ACCOUNTING
}

\author{
18-20 June, 2021 \\ Brussels, Belgium
}

Li, S., S. Ho Park, and R. Shuji Bao. 2014. How much can we trust the financial report? Earnings management in emerging economies. International Journal of Emerging Markets 9 (1):33-53.

Li, S., D. D. Selover, and M. Stein. 2011. "Keep silent and make money": Institutional patterns of earnings management in China. Journal of Asian Economics 22 (5):369-382.

Lin, P. T., M. R. Hutchinson, and M. Percy. 2009. The role of the audit committee and institutional investors in constraining earnings management: evidence from Chinese firms listed in Hong Kong. Paper read at Proceedings of Accounting \& Finance Association of Australia \& New Zealand Annual Conference 2009.

Lipton, M., and J. W. Lorsch. 1992. A modest proposal for improved corporate governance. The business lawyer 48 (1):59-77.

Lorca, C., J. P. Sánchez-Ballesta, and E. García-Meca. 2011. Board effectiveness and cost of debt. Journal of Business Ethics 100 (4):613-631.

Lubatkin, M., P. J. Lane, S. Collin, and P. Very. 2007. An embeddedness framing of governance and opportunism: towards a cross- nationally accommodating theory of agency. Journal of Organizational Behavior 28 (1):43-58.

McKEE, T. E. 2005. Earnings management: an executive perspective: South-Western Pub.

Md Zaini, S., G. Samkin, U. Sharma, and H. Davey. 2018. Voluntary disclosure in emerging countries: a literature review. Journal of Accounting in Emerging Economies 8 (1):2965.

Menon, K., and J. D. Williams. 1994. The use of audit committees for monitoring. Journal of Accounting and Public Policy 13 (2):121-139.

Millar, C. C., T. I. Eldomiaty, C. J. Choi, and B. Hilton. 2005. Corporate governance and institutional transparency in emerging markets. Journal of Business Ethics 59 (12):163-174.

Mintzberg, H., and H. Mintzberg. 1983. Power in and around organizations. Vol. 142: Prentice-Hall Englewood Cliffs, NJ.

Mitton, T. 2002. A cross-firm analysis of the impact of corporate governance on the East Asian financial crisis. Journal of Financial Economics 64 (2):215-241.

Niu, F. F. 2006. Corporate governance and the quality of accounting earnings: a Canadian perspective. International Journal of Managerial Finance 2 (4):302-327.

Omran, M. M., A. Bolbol, and A. Fatheldin. 2008. Corporate governance and firm performance in Arab equity markets: does ownership concentration matter? International review of law and economics 28 (1):32-45.

Osma, B. G. 2008. Board independence and real earnings management: The case of R\&D expenditure. Corporate Governance: An International Review 16 (2):116-131.

Park, Y. W., and H.-H. Shin. 2004. Board composition and earnings management in Canada. Journal of Corporate Finance 10 (3):431-457.

Peasnell, K. V., P. Pope, and S. Young. 2000a. Accrual management to meet earnings targets: UK evidence pre-and post-Cadbury. The British Accounting Review 32 (4):415-445. 


\title{
$7^{\text {th }}$ International Conference On Opportunities and Challenges In MANAGEMENT, ECONOMICS and ACCOUNTING
}

\author{
18-20 June, 2021 \\ Brussels, Belgium
}

Peasnell, K. V., P. F. Pope, and S. Young. 2005. Board monitoring and earnings management: Do outside directors influence abnormal accruals? Journal of Business Finance \& Accounting 32 (7- 8):1311-1346.

Peni, E., and S. Vähämaa. 2010. Female executives and earnings management. Managerial Finance.

Pillai, R., and H.-A. N. Al-Malkawi. 2018. On the relationship between corporate governance and firm performance: Evidence from GCC countries. Research in International Business and Finance 44:394-410.

Piot, C., and R. Janin. 2007. External auditors, audit committees and earnings management in France. European Accounting Review 16 (2):429-454.

Rahman, R. A., and F. H. M. Ali. 2006. Board, audit committee, culture and earnings management: Malaysian evidence. Managerial Auditing Journal 21 (7):783-804.

Rossi, F., and R. J. Cebula. 2015. Does the board of directors affect the extent of corporate R\&D? Evidence from Italian listed companies. Economics Bulletin 35 (4):2567-2580.

Roychowdhury, S. 2006. Earnings management through real activities manipulation. Journal of accounting and economics 42 (3):335-370.

Sánchez- Ballesta, J. P., and E. García- Meca. 2007. Ownership structure, discretionary accruals and the informativeness of earnings. Corporate Governance: An International Review 15 (4):677-691.

Sarhan, A. A., and C. G. Ntim. 2019a. Corporate boards, shareholding structures and voluntary disclosure in emerging MENA economies. Journal of Accounting in Emerging Economies 9 (1):2-27.

Schipper, K. 1989. Commentary on earnings management. Accounting Horizons 3 (4):91-102. Scott, W. R. 1997. Financial accounting theory. Vol. 2: Prentice hall Upper Saddle River, NJ.

Seal, W. 2006. Management accounting and corporate governance: An institutional interpretation of the agency problem. Management Accounting Research 17 (4):389408.

SEC. 1999. Securities and Exchange Commission (SEC). Final Rule: Audit Committee Disclosure. Washington, D.C. SEC.

Skinner, D. J., and R. G. Sloan. 2002. Earnings surprises, growth expectations, and stock returns or don't let an earnings torpedo sink your portfolio. Review of Accounting Studies 7 (2-3):289-312.

SOX, S.-O. A. 2002. Public Law No. 107-204. GPO: Washington, DC.

Srinidhi, B. N., and F. A. Gul. 2007. The differential effects of auditors' nonaudit and audit fees on accrual quality. Contemporary Accounting Research 24 (2):595-629.

Suhomlinova, O. 2006. Toward a Model of Organizational Co- Evolution in Transition Economies. Journal of management studies 43 (7):1537-1558.

Sun, J., G. Liu, and G. Lan. 2011. Does female directorship on independent audit committees constrain earnings management? Journal of Business Ethics 99 (3):369-382.

Torchia, M., A. Calabrò, and M. Huse. 2011. Women directors on corporate boards: From tokenism to critical mass. Journal of Business Ethics 102 (2):299-317. 


\section{$7^{\text {th }}$ International Conference On Opportunities}

and Challenges In MANAGEMENT,

\section{ECONOMICS and ACCOUNTING}

\section{8-20 June, 2021 \\ Brussels, Belgium}

Triki Damak, S. 2018. Gender diverse board and earnings management: evidence from French listed companies. Sustainability Accounting, Management and Policy Journal 9 (3):289-312.

Vafeas, N. 1999. Board meeting frequency and firm performance. Journal of Financial Economics 53 (1):113-142. . 2000. Board structure and the informativeness of earnings. Journal of Accounting and Public Policy 19 (2):139-160.

Visvanathan, G. 2008. Corporate governance and real earnings management. Academy of Accounting and Financial Studies Journal 12 (1):9.

Waweru, N. M., and N. P. Prot. 2018. Corporate governance compliance and accrual earnings management in eastern Africa: Evidence from Kenya and Tanzania. Managerial Auditing Journal 33 (2):171-191.

Winship, C., and S. L. Morgan. 1999. The estimation of causal effects from observational data. Annual review of sociology 25 (1):659-706.

Wooldridge, J. 2003. Introductory econometrics: a modern approach, ed Mason: Thomson South-Western. List of appendices.

Xie, B., W. N. Davidson, and P. J. DaDalt. 2003. Earnings management and corporate governance: the role of the board and the audit committee. Journal of Corporate Finance 9 (3):295-316.

Yermack, D. 1996. Higher market valuation of companies with a small board of directors. Journal of Financial Economics 40 (2):185-211.

Young, M. N., M. W. Peng, D. Ahlstrom, G. D. Bruton, and Y. Jiang. 2008. Corporate governance in emerging economies: A review of the principal-principal perspective. Journal of management studies 45 (1):196-220.

Zalata, A. M., V. Tauringana, and I. Tingbani. 2018. Audit committee financial expertise, gender, and earnings management: Does gender of the financial expert matter? International Review of Financial Analysis 55:170-183. 